This document is confidential and is proprietary to the American Chemical Society and its authors. Do not copy or disclose without written permission. If you have received this item in error, notify the sender and delete all copies.

\title{
Tertiary Carbonate Side Chains: Easily Tuneable Thermo- Labile Breaking Points for Controlling the Solubility of Conjugated Polymers
}

\begin{tabular}{|r|l|}
\hline Journal: & Chemistry of Materials \\
\hline Manuscript ID: & cm-2015-00549z.R1 \\
\hline Manuscript Type: & Article \\
\hline Date Submitted by the Author: & 20 -Mar-2015 \\
\hline Complete List of Authors: & $\begin{array}{l}\text { Kuhn, Marius; Heidelberg University, Institute for Organic Chemistry } \\
\text { Ludwig, Jens; Karlsruhe Institute of Technology, Light Technology Institute } \\
\text { Marszalek, Tomasz; Max Planck Institute for Polymer Research, } \\
\text { Adermann, Torben; Heidelberg University, Institute for Organic Chemistry } \\
\text { Pisula, Wojciech; Max Planck Institute for Polymer Research, } \\
\text { Müllen, Klaus; Max-Planck-Institute for Polymer Research, } \\
\text { Colsmann, Alexander; Karlsruhe Institute of Technology (KIT), Light } \\
\text { Technology Institute } \\
\text { Hamburger, Manuel; Heidelberg University, Institute for Organic Chemistry }\end{array}$ \\
\hline
\end{tabular}




\title{
Tertiary Carbonate Side Chains: Easily Tuneable Thermo-
} Labile Breaking Points for Controlling the Solubility of Conjugated Polymers

\author{
Marius Kuhn, a)d) Jens Ludwig, ${ }^{\text {b) }}$ Tomasz Marszalek, ${ }^{c)}$ Torben Adermann, ${ }^{\text {a)d }}$ Wojciech Pisula, ${ }^{c)}$ \\ Klaus Müllen, ${ }^{\text {cd) }}$ Alexander Colsmann, ${ }^{\text {b) }}$ Manuel Hamburger ${ }^{\text {a)d }) *}$ \\ a) Institute of Organic Chemistry, Heidelberg University, Im Neuenheimer Feld 270, 69120 \\ Heidelberg, Germany \\ b) Light Technology Institute, Karlsruhe Institute of Technology (KIT), Engesserstrasse 13, 76131 \\ Karlsruhe, Germany \\ c) Max Planck Institute for Polymer Research, Ackermannweg 10, 55128 Mainz, Germany \\ d) InnovationLab GmbH, Speyerer Strasse 4, 69115 Heidelberg, Germany
}

\begin{abstract}
Breakpoints are not exclusive to tennis: We present a new class of solubilizing groups for conjugated polymers which enable solution processing of multi-layer devices. Conjugated polymers in organic devices are sometimes difficult to process due to their limited solubility. Well soluble polymers decorated with alkyl side chains, however, introduce new challenges for thin-film deposition: Using the same solvent for multiple layers can dissolve the already applied layers. In this work we introduce a new class of thermo-labile groups which reduce the solubility of conjugated polymers after thermal treatment. Following a very modular approach, we can tune the temperature of the thermo-cleavage between 140 and $200{ }^{\circ} \mathrm{C}$. This enables the fabrication of organic solar cells and field-effect transistors (FETs) with robust, solvent-resistant active layers.
\end{abstract}




\section{Introduction}

The unique optical, electrical, and film-forming properties of $\pi$-conjugated polymers enable various optoelectronic applications. ${ }^{1}$ However, using soluble polymers opens new processing challenges for the fabrication of more sophisticated device architectures. To make conjugated organic materials solution-processable, the introduction of solubilizing groups is often necessary, ${ }^{2}$ although these groups can dramatically influence the solid-state structure of these compounds (e.g. their overall crystallinity or packing). ${ }^{3,4,5,6}$ It is hardly possible to use the same or similar solvents for the deposition of consecutive layers, because of the dissolution of the layers that were already applied. Different approaches addressed this issue which are based on crosslinking, ${ }^{7,8}$ the use of orthogonal solvents, ${ }^{9,10}$ or treatment with an external stimulus, such as heat, ${ }^{11,12,13}$ all to prevent the dissolution of the previously formed layers. Especially, the treatment of the processed layers with heat, first reported by the Frechét group11 and made technologically viable by the Krebs group, ${ }^{12}$ using carboxylic acid ester pyrolysis/decarboxylation as thermo-cleavage for polythiophenes, ${ }^{14,15}$ set the basis for our work. The disadvantage of this particular approach is the direct connection of the ester group to the polymer backbone which causes changes in the electronic properties of the polymers as observed for various substituted polythiophenes. ${ }^{16}$ Another drawback is the high decarboxylation temperature $\left(300{ }^{\circ} \mathrm{C}\right)$ that is necessary to yield a semiconducting polythiophene which is compatible only with very heat-resistant flexible substrates. ${ }^{17}$

In this paper we show that placing a spacer between the polymer backbone and the cleavable side chain helps to improve both issues. Although our spacer can universally attached to various conjugated polymers, we deliberately chose polythiophenes as the investigated model system to allow comparison to the literature. The electronic nature of the polythiophene remains unperturbed by the bond scissions before as well as after heat treatment. To lower the cleavage temperature, we introduce a new thermo-labile group which is based on unsymmetrical carbonates with one tertiary alcohol. Leaving a hydroxyl function on the polymeric backbone after thermal removal, these carbonates and their cleavage temperature can be modified by changing the structure of the solubilizing side chain. This is very important for the goal of printing, drying and pyrolysing these polymers (poly(3-(2-((alkoxycarbonyl)oxy)ethyl)thiophen-2,5-diyls P3COET) on low-cost flexible substrates such as polyethylene terephthalate (PET), as this limits the potential process temperatures to around $140{ }^{\circ} \mathrm{C}$. 


\section{Results and discussion}

\subsection{Synthesis}

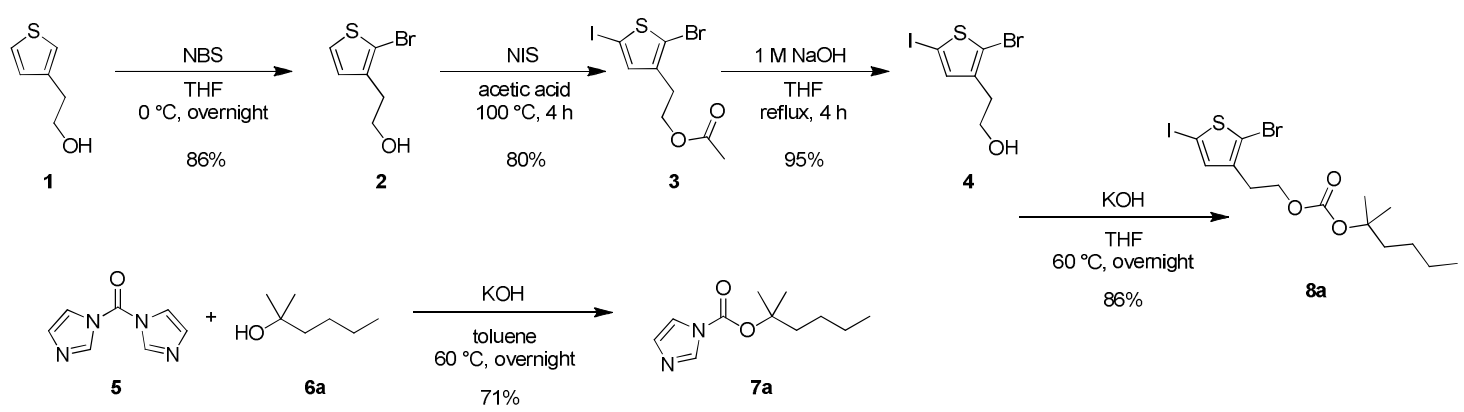

Scheme 1: Synthesis of hydroxyl-alkyl functionalized thiophene monomer 4 and its modification with a thermolabile solubilizing carbonate ester.

The synthetic route to the thermo-cleavable thiophene monomer is outlined in Scheme 1. The synthesis of the thiophene building block was carried out by a bromination of commercially available 2-(3-thienyl)ethanol (1) with $N$-bromosuccinimide (NBS), iodination with $\mathrm{N}$-iodosuccinimide (NIS) and hydrolysis of the resulting ester 3 to yield 2-(2-bromo-5iodothiophen-3-yl)ethanol (4). The ethandiyl spacer of the 2-(2-bromo-5-iodothiophen-3$\mathrm{yl}$ )ethanol (4) was chosen to exclude interference of the carbonate and the hydroxyl function after the cleavage, respectively, with the polymer backbone. It also allows varying the functional groups on the carbonate in a last step before polymerization.

The imidazole- $N$-carboxylic ester 7 was obtained by coupling 2-methylhexan-2-ol (6a) and $1,1^{\prime}$-carbonyldiimidazole (CDI, 5), according to the synthetic procedure by Rannard. ${ }^{18}$ The reason for using 2-methylhexan-2-ol (6a) as solubilizing alkyl chain was a compromise, given that the solubility between the uncleaved and cleaved polymer should be maximized while on the other hand producing volatile fragments. $11^{12}$

The synthesis of the final carbonate 9a could be improved by switching the solvent from toluene $(50 \%$ yield) to tetrahydrofuran ( $86 \%$ yield). The polymerization (9a to poly-9a, Scheme 2) was performed using the Kumada catalyst transfer polymerization (KCTP) reported by Yokozawa. ${ }^{19}$ The low reaction temperature is ideal for the polymerization of thermo-labile thiophenes $\mathbf{9}$, so that no cleavage of the thermo-labile solubilizing chains can occur. 


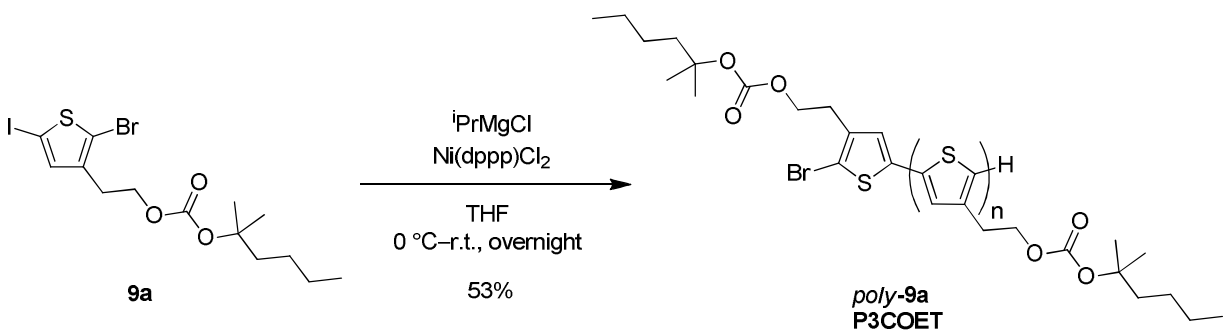

Scheme 2: KCT Polymerization of the thermo-labile thiophene monomer 9a to give P3COET poly-9a.

After precipitation from methanol and Soxhlet extraction, the new P3COET polymer poly-9a was characterized by size exclusion chromatography, while the regioregularity was measured by ${ }^{1} \mathrm{H}$ NMR spectroscopy. The P3COETs were purified and fractionated by Soxhlet extraction with different solvents (methanol followed by acetone and chloroform). The methanol fraction contained only monomers and oligomers, the acetone and chloroform fractions provided two polythiophenes: acetone fraction (39\%): $M_{n}=15.3 \mathrm{~kg} / \mathrm{mol}, M_{w}=24.6$ $\mathrm{kg} / \mathrm{mol}, \mathrm{PDI}=1.6$; chloroform fraction (15\%): $\mathrm{M}_{\mathrm{n}}=41.0 \mathrm{~kg} / \mathrm{mol}, \mathrm{M}_{\mathrm{w}}=45.6 \mathrm{~kg} / \mathrm{mol}, \mathrm{PDI}=1.1$.

\subsection{Characterization of poly-9a and its pyrolysis product}

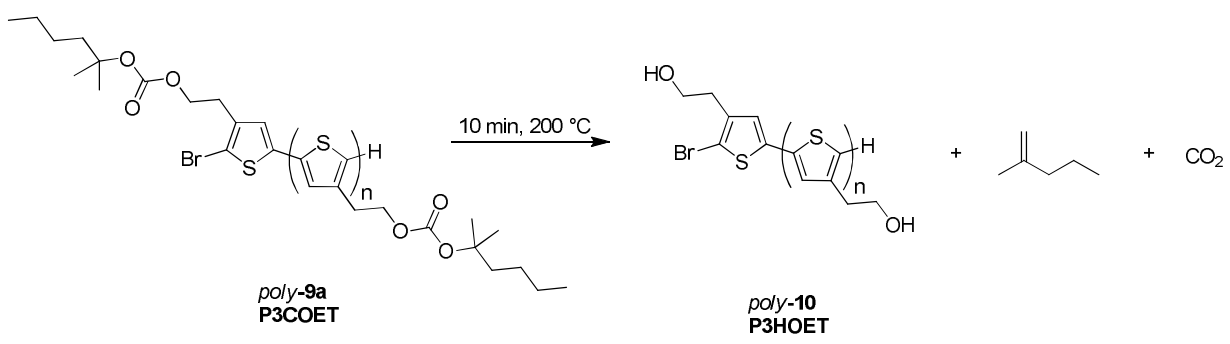

Scheme 3: The decomposition reaction of P3COET poly-9a to P3HOET poly-10 after heating at $200{ }^{\circ} \mathrm{C}$ for 10 minutes. 


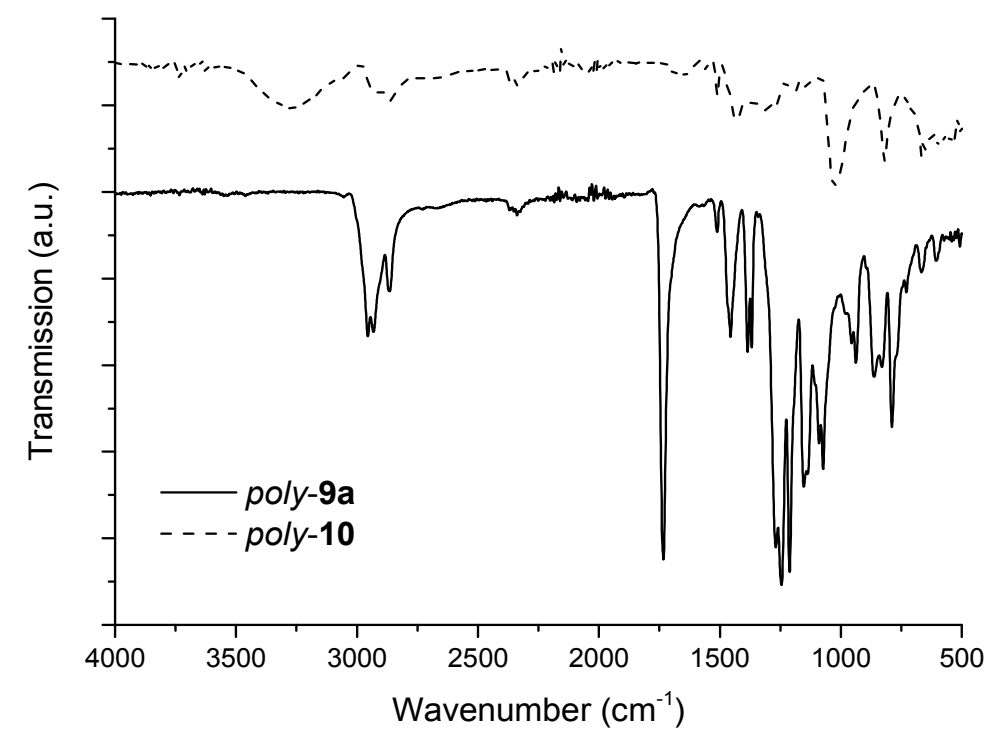

Figure 1: IR spectra of P3COET poly-9a (solid) and P3HOET poly-10 (dashed).

IR spectroscopy is a very convenient analytical characterization technique to indicate whether the polymer consists of carbonates only or already has some cleaved functionalities on the backbone (i.e. alcohols). IR-spectra before (dashed) and after (solid) the cleavage clearly show the split-off of the solubilizing group (Figure 1). The carbonates in poly-9a give rise to a strong band at $1737 \mathrm{~cm}^{-1}$ which can be assigned to the carbonyl stretching mode. After the cleavage, the carbonyl band disappears completely and the liberated alcohol functionality $\left(3230 \mathrm{~cm}^{-1}\right.$ ) of P3HOET poly-10 (poly-3-(2-hydroxyethyl)thiophene-2,5-diyl) can be detected.

The relative (in-)stability of the P3COETs was investigated by thermogravimetric analysis (TGA) in conjunction with differential scanning calorimetry (DSC) in the temperature range up to $300{ }^{\circ} \mathrm{C}$ (Figure 2). The carrier gas leaving the furnace was analyzed by mass spectrometry and Fourier transform infrared spectroscopy (TGA-MS-FTIR, see ESI). These measurements corroborate the evaporation of 2-methyl-2-hexene and carbon dioxide from the sample starting at $180^{\circ} \mathrm{C}$ reaching its maximum at $200^{\circ} \mathrm{C}$. 


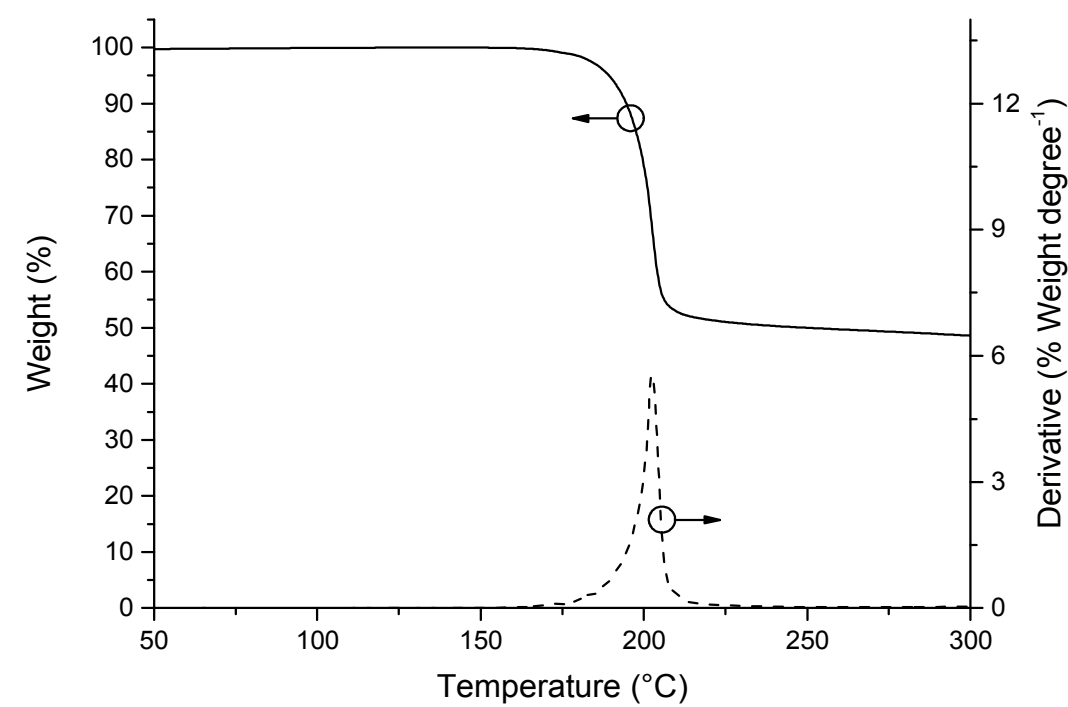

Figure 2: Thermo-gravimetric analysis of P3COET poly-9a in the temperature range of $50-300{ }^{\circ} \mathrm{C}$. The data was recorded at an increasing temperature of $10{ }^{\circ} \mathrm{C} \mathrm{min}{ }^{-1}$ under nitrogen atmosphere. A derivative weight loss curve has been included to indicate the point with the most apparent weight loss.

The optical and electronic properties of the carbonate-functionalized polythiophene poly-9a were investigated by UV-Vis spectroscopy and cyclic voltammetry (CV) measurements (see Supporting Information). The introduction of the carbonate with a $\mathrm{C}_{2}$-spacer has a small effect on the UV-Vis spectra of the polythiophene. This hints to a slightly higher nonplanarity of the conjugated backbone than in common poly(3-hexylthiophene) (P3HT) because of the different length and steric demand of the solubilizing alkyl chain. 3 The CV measurement (poly-9a film in acetonitrile against $\mathrm{Fc} / \mathrm{Fc}^{+}$) confirms the equal electronic properties of the polythiophene poly-9a $\left(\mathrm{E}_{\mathrm{ox}}=0.52 \mathrm{~V}\right)$ compared to $\mathrm{P} 3 \mathrm{HT} .^{20}$

\subsection{Control of cleavage temperature}

To enable the use of our thermo-labile polymers on low-cost flexible substrates (like e.g. PET), their structure should be modified to reduce the cleavage temperature to around $140^{\circ} \mathrm{C}$. Ab initio and experimental studies by Van Speybroeck revealed that a six-membered cyclic transition state is required to have an optimal geometry while the $\mathrm{C}_{\alpha}-\mathrm{O}$ bond dissociation is the rate-determining step. Stabilization of the positive charge in the $\mathrm{C}_{\alpha}$ position affects an acceleration of the reaction rate. The last step is a $\beta$ - $\mathrm{H}$-elimination or synelimination. $^{2122}$ 
According to this mechanism, it is possible to tune the elimination temperature by changing the cation-stabilizing properties of the side chain. Based on this rationale, we set out to prepare derivatives changing the alkyl into an alkenyl $(\mathbf{6 h}-\mathbf{j})$ or alkinyl $(\mathbf{6 e}-\mathbf{g})$ side chains, which form mesomerically stabilized cations and eventually lead to conjugated double bonds after elimination. The two methyl groups or a cyclic group next to the alcohol are necessary for stabilization and simultaneously provide $\beta-\mathrm{H}$ for the pyrolysis. The corresponding alcohols were synthesized by nucleophilic addition of Grignard reagents to carboxyl functions or lithiated alkynes to acetone, cyclopentanone or cyclohexanone, respectively. All synthesized alcohols were stable and most of them could be obtained in good to excellent yields (see Supporting Information).

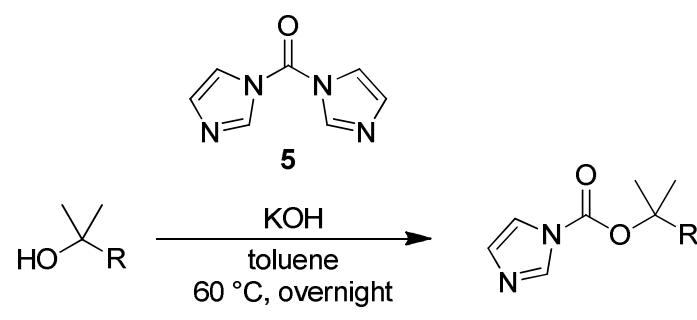

$6 \mathrm{a}-\mathrm{j}$

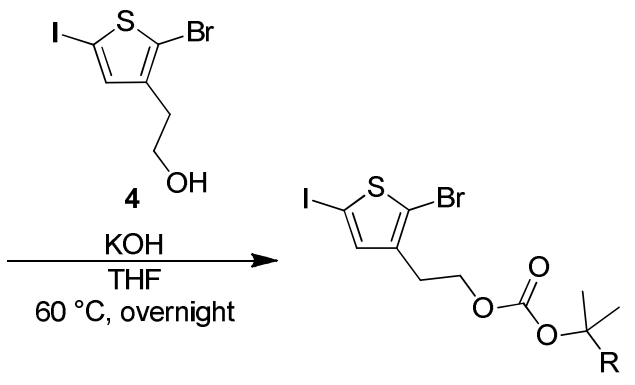

$9 a-f$

Scheme 4: Syntheses of the 3-(2-((alkoxycarbonyl)oxy)ethyl)thiophene monomers 9, starting from tertiary alcohols 6.

Table 1: Chemical structures and yields of the alcohols, carboxyl esters and carbonates prepared in this study.

\begin{tabular}{|c|c|c|c|}
\hline $\begin{array}{l}\text { Solubilizing } \\
\text { group }\end{array}$ & Alcohol, yield & $\begin{array}{c}\text { Imidazole- } N \text { - } \\
\text { carboxylic ester, yield }\end{array}$ & $\begin{array}{c}\text { Carbonate, } \\
\text { yield }\end{array}$ \\
\hline & $6 a,-^{a}$ & $7 a, 86 \%$ & $9 a, 86 \%$ \\
\hline & $6 b,-^{a}$ & $7 b, 70 \%$ & $9 b, 84 \%$ \\
\hline & $6 c, 70 \%$ & 7c, $31 \%$ & 9c, 91\% \\
\hline & $6 d, 45 \%$ & $7 d, 46 \%$ & $9 d, 74 \%$ \\
\hline & $6 e, 78 \%$ & $7 e, 74 \%$ & $9 e, 90 \%{ }^{c}$ \\
\hline
\end{tabular}


${ }^{a}$ Commercially available; ${ }^{b}$ no imidazole- $N$-carboxylic esters isolated, but the decarboxylated $\mathrm{N}$-substituted imidazole $\mathbf{8 h} \mathbf{h} \mathbf{i}$; ${ }^{c}$ triethylamine added for purification by column chromatography.

The synthesis of the imidazole- $N$-carboxylic esters 7 proved necessary for the synthesis of the asymmetric carbonates and were obtained by coupling the appropriate alcohol 6 and 1,1'-carbonyldiimidazole (CDI, 5). Interestingly, during these reactions or their workup some imidazole- $N$-carboxylic esters already decomposed. The CDI-coupling of allylic or benzylic alcohols did not yield the imidazole- $N$-carboxylic esters but the decarboxylated $N$ substituted imidazoles ( $\mathbf{8} \mathbf{h}-\mathbf{j}$, see Supporting Information). This was a first hint that some imidazole- $N$-carboxylic esters and the corresponding carbonates were not stable enough to synthesize a polymer. The carbonate monomers 9 finally were obtained by reacting the imidazole- $N$-carboxylic esters 7 with 2-(2-bromo-5-iodothiophen-3-yl)ethanol (4). For some of the monomers (9e and 9f), triethylamine had to be added to the eluent during purification by column chromatography, the silica gel otherwise being too acidic for the carbonate groups. The use of acidic additives to lower the cleaving temperature has already been shown by the Krebs group. ${ }^{23}$ The yields of the respective imidazole- $N$-carboxylic ester syntheses allow a good forecast for the stability of the resulting carbonates $\mathbf{9}$. We observed that imidazole- $N$-carboxylic ester $\mathbf{7 g}$ with a cyclopentyl and alkinyl side chain (entry 7 ) was difficult to isolate and that the carbonate $9 \mathrm{~g}$ could not be obtained. The cyclopentyl group resulted in less stable compounds than the cyclohexyl. 


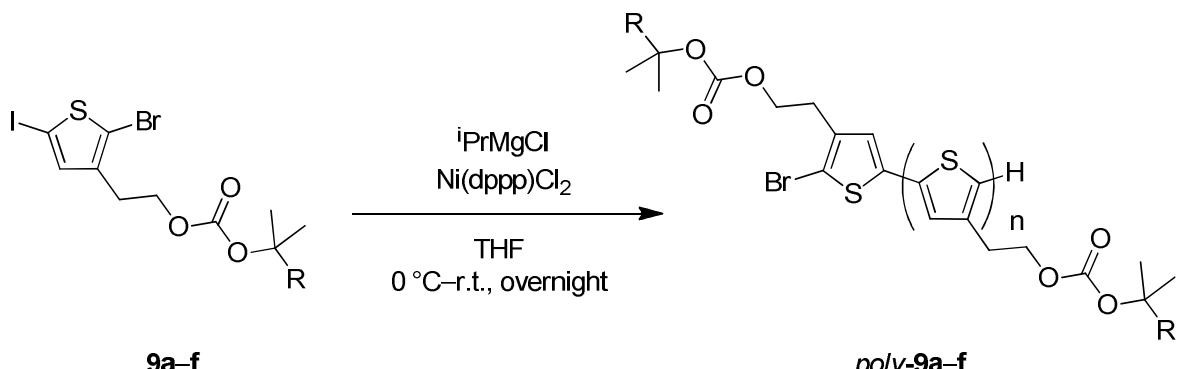

$9 a-f$

poly-9a-f

Scheme 5: KCT Polymerization of thermo-labile thiophene monomers 9a-f to obtain a series of P3COETs (cf. Table 2).

With this set of monomers, the corresponding polymers (Table 2) were prepared by KCTP. ${ }^{19}$ The low reaction temperature of this reaction proves ideal for the polymerization of the monomers 9 , since it prohibits the cleavage of the thermo-labile solubilizing chains during polymerization.

Table 2: Chemical structures, yields and properties of P3COETs poly-9a-f obtained by KCT polymerization of 9a-f.

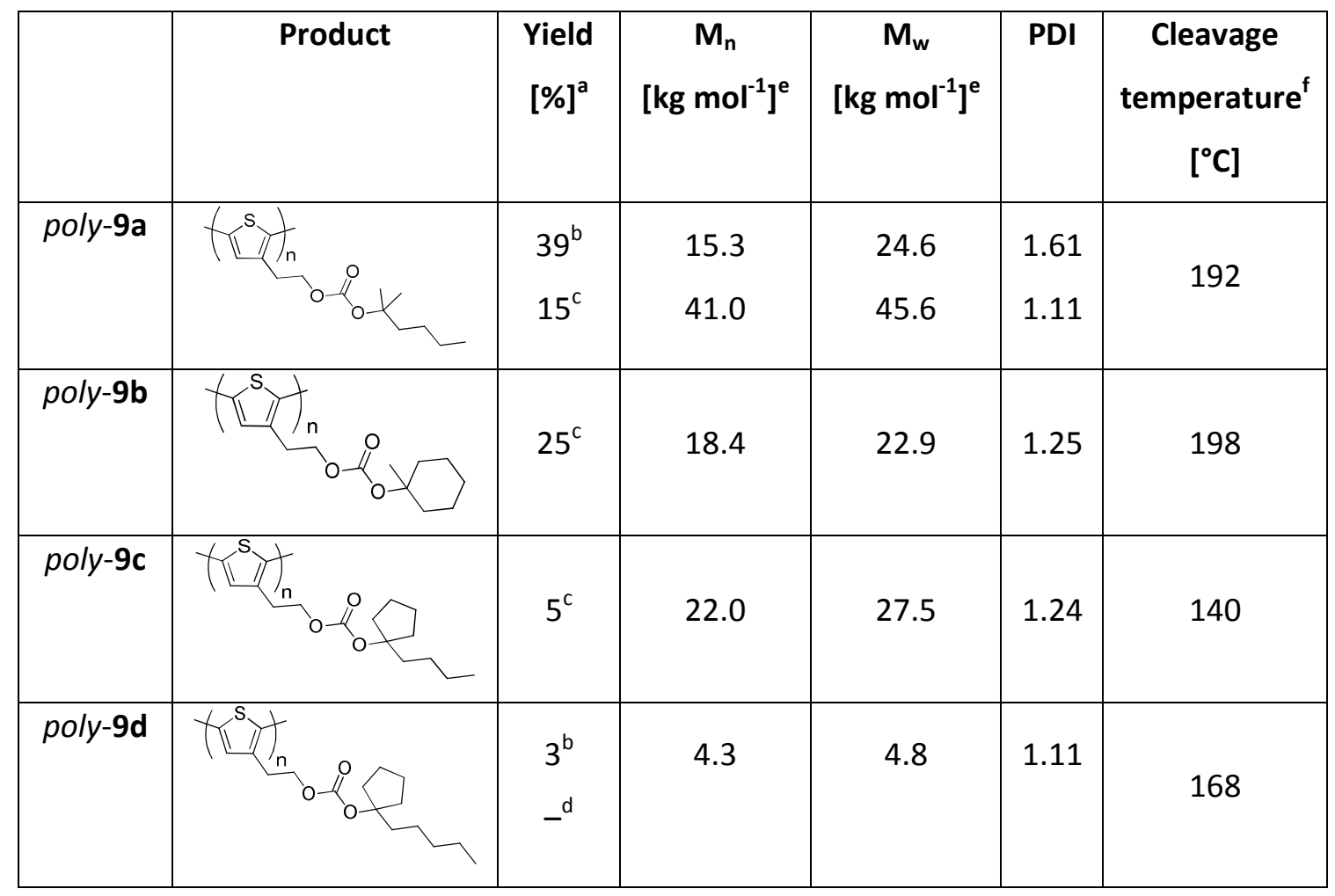




\begin{tabular}{|l|l|l|l|l|l|l|}
\hline poly-9e & 20 & 8.2 & 10.9 & 1.32 & 174 \\
\hline poly-9f & & $20^{\mathrm{c}}$ & 17.9 & 31.7 & 1.77 & 178 \\
\hline
\end{tabular}

${ }^{a}$ After Soxhlet extraction: ${ }^{b}$ acetone-soluble; ${ }^{c}$ chloroform-soluble; ${ }^{d}$ non-soluble fraction in chloroform obtained after cleavage; ${ }^{\mathrm{e}}$ determined by SEC with polystyrene standards in chloroform; 'temperature at $5 \%$ weight loss measured by thermo-gravimetric analysis (at $10^{\circ} \mathrm{C} \mathrm{min}^{-1}$ ).

Table 2 is a compilation of all synthesized P3COETs poly-9a-f. Obviously, the yields correlate with the cleavage temperature of the thermo-labile solubilizing chains and results from the purification method. P3COETs with lower cleavage temperature like poly-9c-f (Table 2) partially cleave during the synthesis or the purification by Soxhlet extraction because of the high temperature and the slight acidic behavior of chloroform. ${ }^{23}$ In this case, formation of insoluble P3HOET poly-10 in the Soxhlet thimble could be observed, but also the soluble polymers poly-9c+d already exhibit a small hydroxyl-band in their IR spectra. The other P3COETs show no hydroxyl vibrations in the IR which is in line with a higher cleavage temperature. The molecular weights $\left(M_{w}\right)$ of the polymers are in the range of $4.8 \mathrm{~kg} \mathrm{~mol}^{-1}$ to $45.6 \mathrm{~kg} \mathrm{~mol}^{-1}$ and are not linked to the yields or the (in-)stability (entry 3). The dispersity (PDI) of the polymers is low. Figure 3 shows the thermal behavior of the P3COETs poly-9a-f as normalized TGA curves in the temperature range of $100-250^{\circ} \mathrm{C}$. The range of the thermal cleavage is between $140{ }^{\circ} \mathrm{C}$ (poly-9c, entry 3) and $198{ }^{\circ} \mathrm{C}$ (poly-9b, entry 2). The polymers with cyclopentyl groups (poly-9c and poly-9d; entry 3+4) are less stable than the polymers with alkynyl groups (poly-9e and poly-9f; entry 5+6).The poly-9b with a cyclohexyl group (entry 2) exhibits the highest cleavage temperature. The difference in the normalized TGA curve shapes depends on the boiling point of the alkene generated during the pyrolysis. 


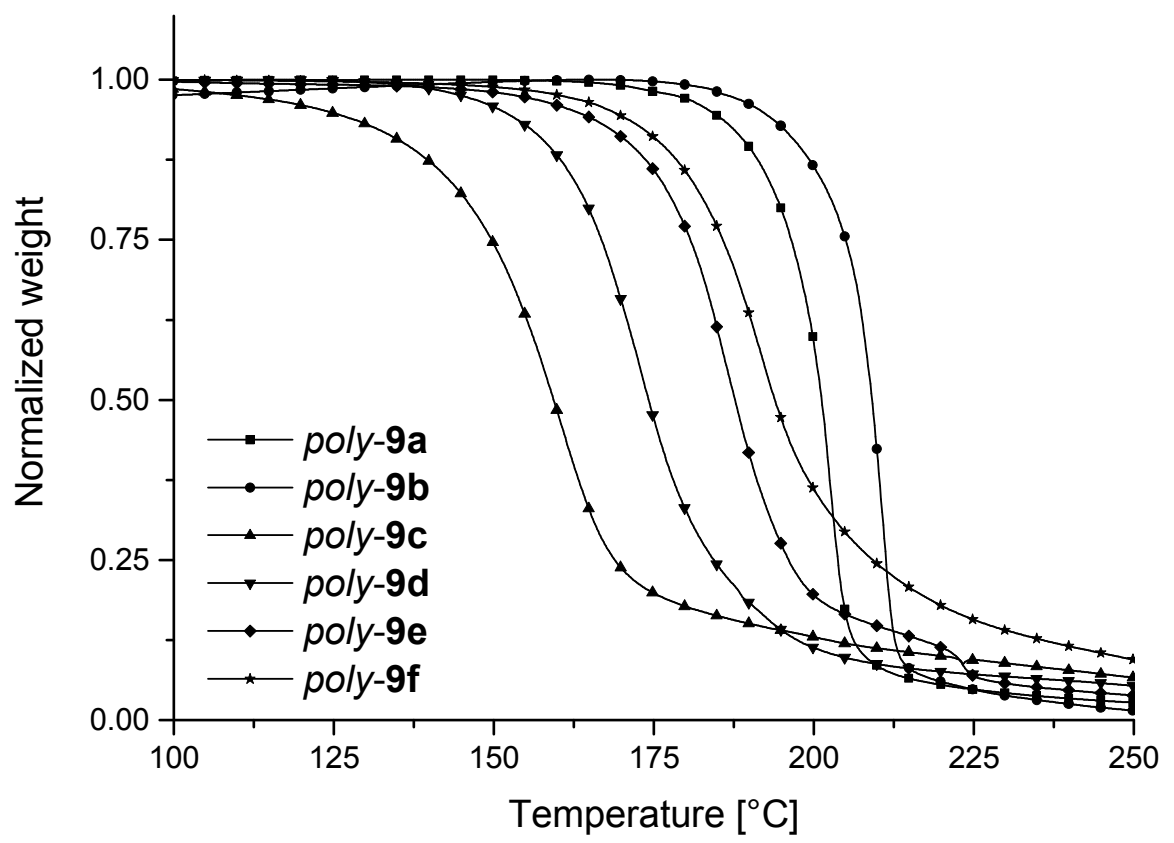

Figure 3: Normalized TGA curves of the P3COETs poly-9a-f. The data was recorded at an increasing temperature of $10{ }^{\circ} \mathrm{C} \mathrm{min}-1$ under nitrogen atmosphere.

\subsection{Thin film structural analysis}

The control over the surface arrangement of conjugated polymers is essential for their application in electronic devices. Generally, transistors require an edge-on polymer arrangement favoring the charge carrier transport parallel to the dielectric surface. ${ }^{24}$ On the other hand, the efficiency of solar cells can be improved by a face-on assembly when the $\pi$-stacking direction is oriented perpendicular to the substrate and thus in the direction of the charge carrier transport. Different approaches related to polymer design and processing have been reported to control the surface organization of polymers. For instance, the morphology of P3HT thin-films can be tuned by substrate treatment ${ }^{25}$ and the solvents used for thin-film fabrication. ${ }^{26}$ The annealing of a polymer at its melting temperature can also change the surface organization as in the case of poly-naphthalene-bithiophene from faceon, obtained after spin-coating, to edge-on. ${ }^{27}$ Concerning the polymer design, the organization of $\mathrm{P} 3 \mathrm{HT}$ can be controlled by its regioregularity. ${ }^{28}$ The aggregation in solution also plays an important role and is affected by the polymer interactions. Polymers with bulky substituents reducing aggregation assemble on the surface face-on, while macromolecules 
with strong interactions and subsequent aggregation in solution are arranged edge-on. ${ }^{29}$ In bulk-heterojunction structures for solar cells, PCBM acts like a plasticizer for the conjugated polymers and can induce reorganization of the polymer mostly to face-on, thus enhancing the device efficiency. ${ }^{30}$

\subsubsection{Neat P3COET polymer films}

In order to identify differences in polymer organization before and after thermal cleavage of solution deposited thin films of P3COET poly-9a, grazing incidence wide-angle X-ray scattering (GIWAXS) measurements were performed. Since poly-9a can be applied in at least two different types of devices, field-effect transistors and organic solar cells, two kinds of samples were investigated (pure P3COET and its blend with an acceptor). In the first case, drop-cast or spin-coated neat poly-9a samples were fabricated according to the procedures used for the transistor fabrication (see Supporting Information).
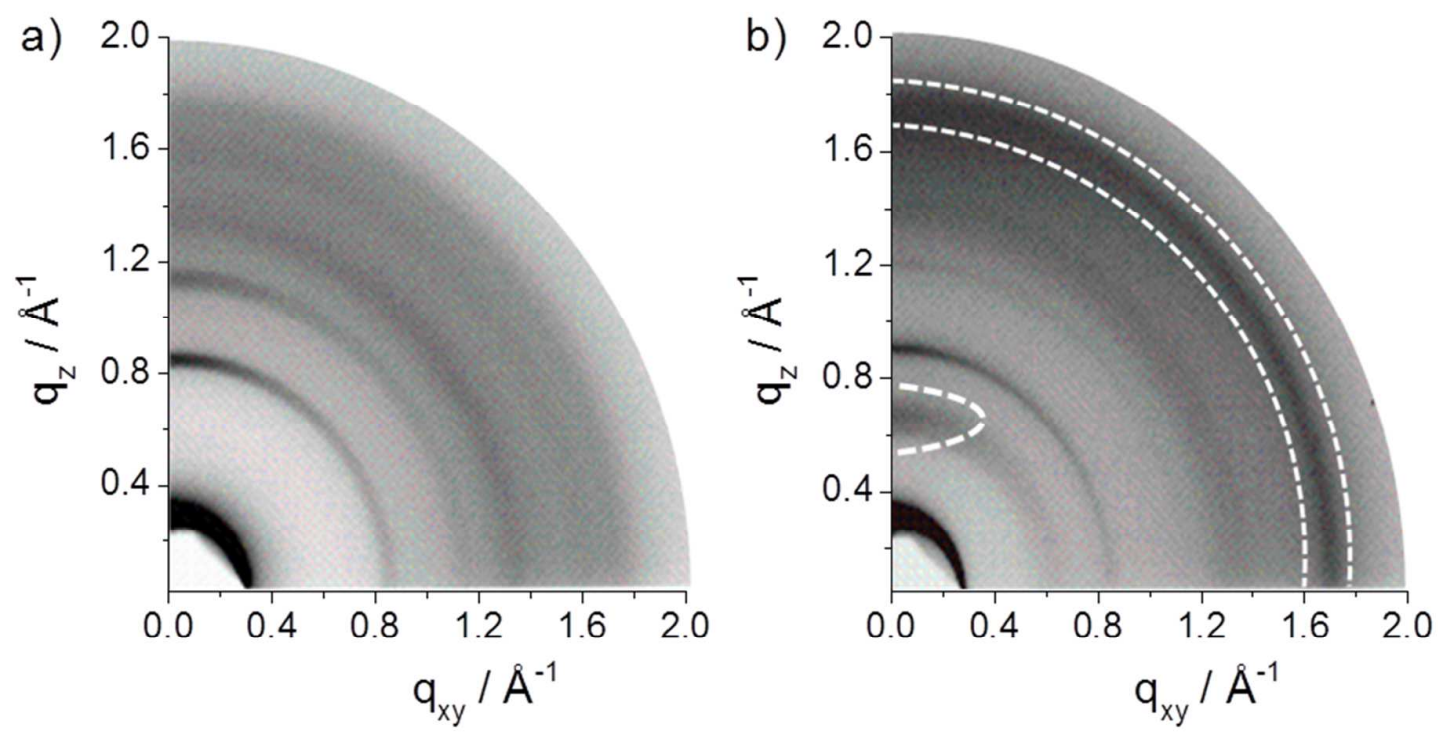

Figure 4: GIWAXS patterns of drop-cast films of poly-9a after annealing (a) at $100{ }^{\circ} \mathrm{C}$ and (b) at $200{ }^{\circ} \mathrm{C}$. Meridional reflection related to the new interlayer and $\pi$-stacking peak are indicated by dashed circles.

Large variation in packing for poly-9a drop-cast films before and after annealing at $200{ }^{\circ} \mathrm{C}$ is evident from the GIWAXS patterns presented in Figure 4. Both patterns reveal quite isotropic reflections indicating a rather random distribution of the crystallites towards the surface. This is not surprising, since the drop-cast films are relatively thick with no preferential growth direction of the polymers. Nevertheless, the maximum intensity of the ho0 reflection on the meridional plane implies certain preference of the polymer orientation 
on the surface. This reflection is assigned to an interlayer distance of $2.20 \mathrm{~nm}$ of layers arranged parallel to the substrate with quasi edge-on polymer backbones. In comparison to regioregular P3HT $(\mathrm{d}=1.57 \mathrm{~nm}),{ }^{31}$ the larger layer spacing obtained for poly-9a is caused by the attached thermally sensitive alkyl chains. In addition, the substituents influence the interaction between polymers. The lack of a corresponding $\pi$-stacking peak of poly-9a before annealing suggests highly disordered polymer packing within the layer structures (Figure 4a). The GIWAXS pattern in Figure $4 \mathrm{~b}$ is obtained for poly-9a after thermal cleavage of the substituents (i.e. P3HOET poly-10). The interlayer distance observed for the unannealed film is slightly reduced from $2.20 \mathrm{~nm}$ to $2.15 \mathrm{~nm}$. In addition, a new reflection on the meridional plane is observed for $q_{z}=0.67 \AA^{-1}$ and $q_{x y}=0 \AA^{-1}$ related to a d-spacing of $0.93 \mathrm{~nm}$. This value is in agreement with the diameter of the polymer after thermal cleavage. The appearance of this reflection indicates the co-existence of two structures with independent interlayer spacings of $2.15 \mathrm{~nm}$ and $0.93 \mathrm{~nm}$. Most probably the thick drop-cast film undergoes only partly the cleavage reaction leading to the formation of both phases. The film heterogeneity is also the reason for the low level of the charge carrier mobility in field-effect transistors of $10^{-5} \mathrm{~cm}^{2} / \mathrm{Vs}$ before and after thermo-cleavage (see Supporting Information). To ensure more homogenously thermo-cleavage in the thin spin-coated samples, the films were treated at lower temperatures for significantly longer annealing times. This process allows thermocleavage through the entire film leading solely to an interlayer distance of $0.93 \mathrm{~nm}$ (Figure S2). In general, the crystallinity of the spin-coated films is lower in comparison to dropcasting due to longer evaporation time of the solvent and thus extended kinetics of the structure growth in the latter case. A further interesting change in the drop-cast film after the cleavage of the substituents is the increased packing order of the polymers as evident from the additional $\pi$-stacking reflection in the wide-angle scattering range related to a distance of $0.37 \mathrm{~nm}$. It can be assumed that the steric demand of the substituent is reduced after thermo-cleavage allowing a stronger interaction between the conjugated P3HOET backbones.

\subsubsection{Polymer:PCBM films}

In order to integrate poly-9a into the absorber layers of bulk-heterojunction organic photovoltaic devices, we studied the thin-film formation of a polymer:fullerene blend upon deposition from solution. Therefore, we dissolved poly-9a and $[6,6]$-phenyl $C_{61}$-butyric acid 
methyl ester (PCBM) 1:0.5 (wt:wt) in 1,2-dichlorobenzene and spin cast the layer from the respective solution. We assessed the bulk-heterojunction homogeneity by atomic force microscopy (AFM). The thin-film topography of films that were annealed at $150{ }^{\circ} \mathrm{C}$, is depicted in Figure 5 . The layers exhibited a root-mean-square roughness $r_{q} \approx 0.36 \mathrm{~nm}$ and did not exhibit any pinholes. Upon annealing at $200{ }^{\circ} \mathrm{C}$ and hence above the cleavage temperature, the surface texture became rougher $\left(r_{q} \approx 4.49 \mathrm{~nm}\right)$ and, besides some larger aggregates, exhibited grains with a typical size of $10 \mathrm{~nm}$ that were randomly distributed all over the layer surface. Most importantly, upon annealing, these layers were almost insoluble in the process solvent, i.e. 1,2-dichlorobenzene.
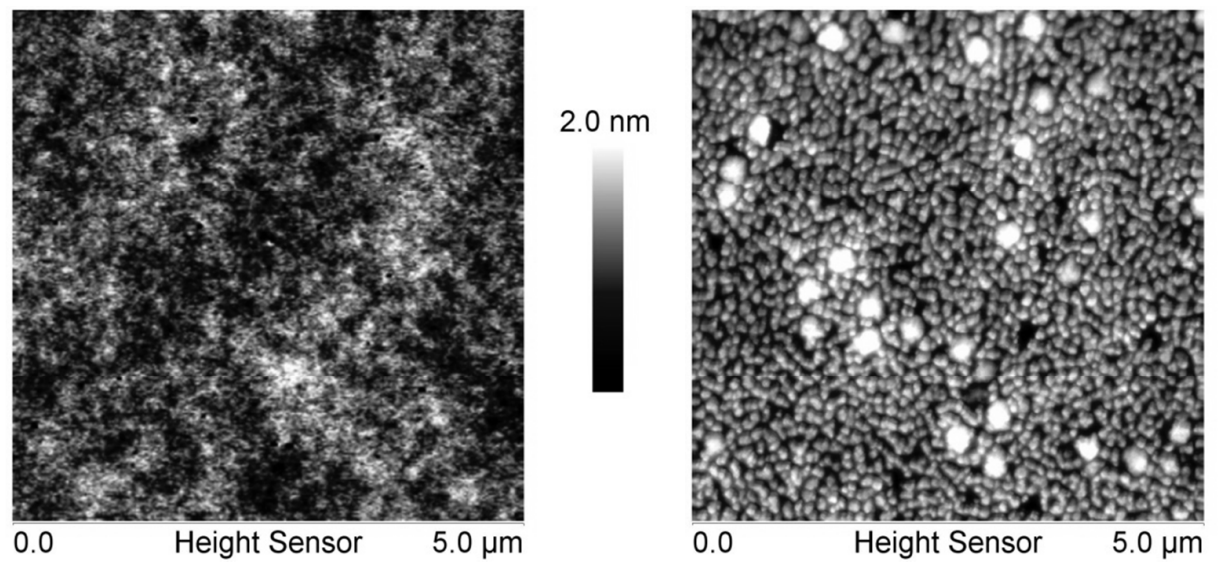

$30.0 \mathrm{~nm}$

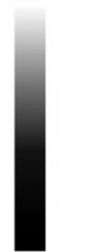

Figure 5: Surface texture of poly-9a:PCBM (1:0.5 wt/wt) films (a) after annealing at $150^{\circ} \mathrm{C}$ and (b) after annealing at $200^{\circ} \mathrm{C}$ and side chain cleavage.

When investigated by X-ray diffraction, the effect of the thermo-cleavage on the polymer packing in poly-9a thin films is even more evident in the bulk-heterojunction structure. Figure 6 depicts the GIWAXS patterns obtained for thin spin-coated poly-9a:PCBM layers on poly(3,4-ethylenedioxythiophene):polystyrenesulfonate (PEDOT:PSS) before and after thermo-cleavage at $200{ }^{\circ} \mathrm{C}$. The film before annealing is quite disordered as only one single peak on the meridional plane at $q_{z}=0.285 \AA^{-1}$ and $q_{x y}=0 \AA^{-1}$ is observed. This reflection is assigned to the poly-9a interlayer distance of $2.20 \mathrm{~nm}$ which is in agreement with the measurement of the drop-cast sample. Identically to the drop-cast film before thermal cleavage, no $\pi$-stacking reflection can be discerned for the spin-coated poly9a:PCBM blend before annealing at $200^{\circ} \mathrm{C}$. As reported in literature, PCBM does not show any crystalline organization up to an annealing temperature of $142{ }^{\circ} \mathrm{C}^{32}$ Annealing above the pyrolysis temperature $\left(20{ }^{\circ} \mathrm{C}\right)$ drastically changes the GIWAXS pattern for the bulk- 
heterojunction structure. The main difference in the obtained pattern is the lack of the small-angle meridional reflection previously assigned to the layer arrangement. Interestingly, in the small-angle equatorial plane a new reflection at $q_{x y}=0.63 \AA^{-1} q_{z}=0 \AA^{-1}$ appears corresponding to a d-spacing of $0.99 \mathrm{~nm}$. This value is in agreement with the changes observed in the drop-cast and the spin-coated poly-9a film after thermal cleavage (Figure S2). However, in the bulk-heterojunction blend, the interlayer reflection moves from the meridional to equatorial plane suggesting a change of the backbone organization from edgeon to face-on. Furthermore, the face-on organization after thermo-cleavage is confirmed by the appearance of the $\pi$-stacking reflection $(0.38 \mathrm{~nm})$ in the wide-angle meridional plane.

In this work, the rearrangement of poly-9a occurs after annealing and thermal cleavage of the substituents. The reorganization is attributed to the film plasticization by PCBM, increasing the mobility of the polymer chains during thermal cleavage. ${ }^{30}$ During this annealing step, PCBM crystalizes as evident from the spot-like reflections observed in the off-meridional range of the pattern (Figure $6 b$ ) which has also been observed in the AFM measurements. ${ }^{32}$ Consequently, the intralayer order increases, while the interlayer distance decreases. The higher order within the layers enhances the charge carrier transport in $\pi$ stacking direction which, after the reorganization, coincides with the direction of the applied electric field in solar cells. Additionally, the shorter interlayer periodicity and less dense isolating alkyl mantle facilitates transport between layers. This increases the dimensionality of the charge carrier transport, allowing an easier by-passing of structural defects such as trapping sites. 
a)

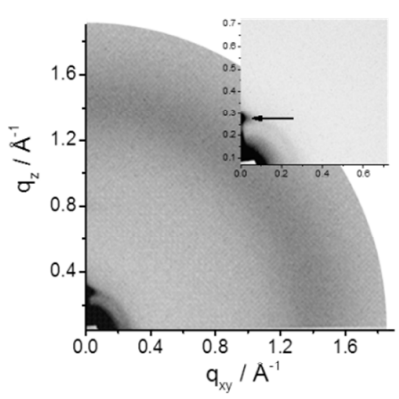

c)

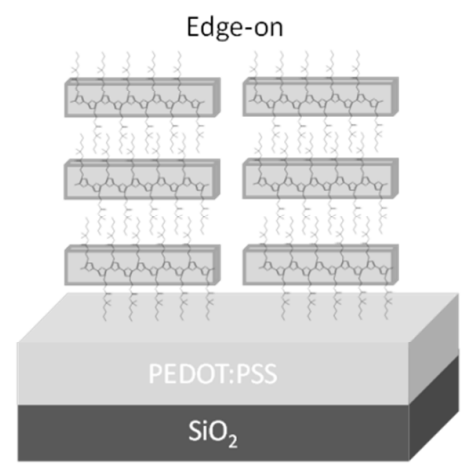

b)

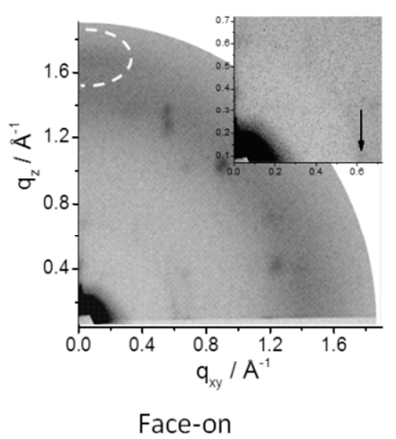

d)

Face-on

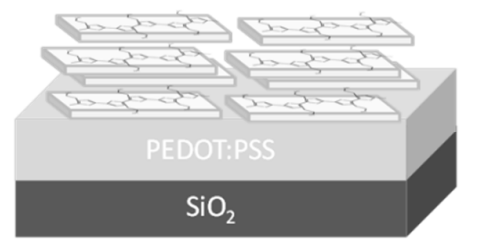

Figure 6: GIWAXS patterns of poly-9a:PCBM thin films on PEDOT:PSS (a) before and (b) after thermo-cleavage at $200{ }^{\circ} \mathrm{C}$ (meridional $\pi$-stacking reflection is indicated by the dashed circle). Insets show the small-range scattering range with the interlayer reflection indicated by an arrow. Schematic illustrations of the poly-9a surface organization obtained after fabrication with (c) edge-on and (d) face-on arrangement after thermal annealing at $200{ }^{\circ} \mathrm{C}$ (due to simplicity, PCBM is omitted).

\subsection{Bulk-heterojunction solar cells}

The good film quality enabled the poly-9a:PCBM (1:0.5 wt/wt) layer integration into organic photovoltaic devices with an ITO/PEDOT:PSS/poly-9a:PCBM/Ca/Al device architecture. The solar cell with the absorber layer that was annealed at $150{ }^{\circ} \mathrm{C}$, i.e., below the cleavage temperature, exhibits very poor performance, particularly due to a very low photo current, as depicted in Figure 7a. Upon annealing at $200{ }^{\circ} \mathrm{C}$ and side chain cleavage, the photo current increases significantly to $4.2 \mathrm{~mA} / \mathrm{cm}^{2}$ and hence the device power conversion efficiency improves to $1.2 \%$. This observation may partly be attributed to the low PCBM load in the bulk-heterojunction which commonly depends on the degree of intercalation of polymer and fullerene. For optimized P3HT:PCBM solar cells, the blend ratio is on the order of $1: 1$. Here, the improvement of the device performance upon annealing at $200{ }^{\circ} \mathrm{C}$ and the removal of the side chains leads to a reduced intercalation. The reduced intercalation in turn enables better device efficiencies with reduced PCBM load. This assumption is supported by the concentration dependent J-V measurements that are depicted in Figure $7 \mathrm{~b}$., where we 

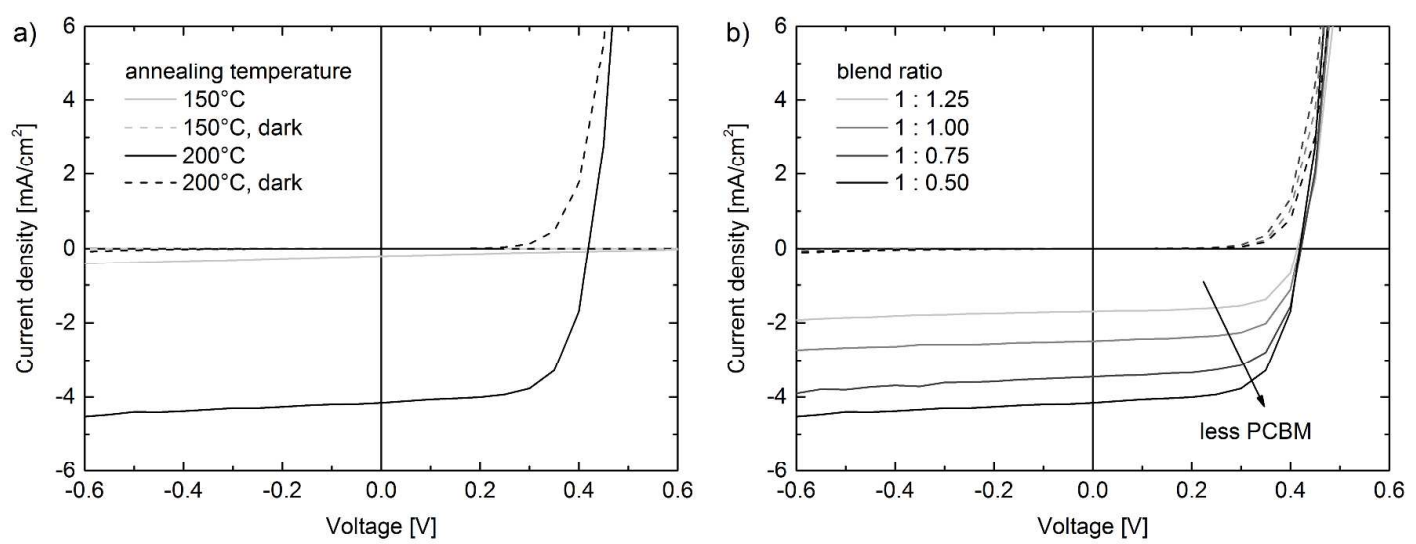

Figure 7: (a) Typical J-V curves of poly-9a:PCBM (1:0.5 wt/wt) solar cells comprising photo-active layers that were annealed below (gray) and above the cleavage temperature(black), i.e., $150{ }^{\circ} \mathrm{C}$ and $200{ }^{\circ} \mathrm{C}$, respectively. (b) PCBM concentration dependent J-V measurements of devices that were annealed at $200^{\circ} \mathrm{C}$. The lower the PCBM load the better is the device performance (dashed lines: dark curve measurement withoumination).

Table1: Solar Cell Parameters for the non-treated solar cell and the thermally treated cells with varying polymer:fullerene ratio.

\begin{tabular}{llllll}
\hline $\begin{array}{l}\text { polymer:fullerene } \\
\text { blend ratio }\end{array}$ & $\begin{array}{l}\text { annealing } \\
\text { temperature }\end{array}$ & $\mathrm{J}_{\mathrm{SC}}\left[\mathrm{mA} / \mathrm{cm}^{2}\right]$ & $\mathrm{V}_{\mathrm{OC}}[\mathrm{V}]$ & $\mathrm{FF}[\%]$ & $\mu_{\text {eff }}[\%]$ \\
\hline $1: 1.25$ & $200^{\circ} \mathrm{C}$ & 1.7 & 0.41 & 68 & 0.5 \\
$1: 1.0$ & $200^{\circ} \mathrm{C}$ & 2.5 & 0.42 & 68 & 0.7 \\
$1: 0.75$ & $200^{\circ} \mathrm{C}$ & 3.4 & 0.42 & 69 & 1.0 \\
$1: 0.5$ & $200^{\circ} \mathrm{C}$ & 4.2 & 0.42 & 66 & 1.2 \\
$1: 0.5$ & $150^{\circ} \mathrm{C}$ & 0.2 & 0.68 & 24 & 0.03 \\
\hline
\end{tabular}

\section{Conclusion}

We synthesized a series of novel carbonate-functionalized thiophene monomers and regioregular polythiophenes P3COETs of variable pyrolysis temperature. By tuning the stabilization of the cleavage fragments, we control the onset of the pyrolysis down to a temperature region which is compatible with low-cost polymeric substrates like PET. TGA measurements in combination with IR spectroscopic studies verify the completeness and the selectivity of the cleavage to the corresponding P3HOET. 
Based on untreated P3COETs, lateral charge transport was observed in TFTs. After the pyrolysis, however, no working TFT could be obtained. On the other hand, the efficiency of the solar cells was dramatically improved upon pyrolysis. This intriguing observation could be rationalized based on GIWAXS measurements in thin films of either pure P3COET, the pyrolysed P3HOET and the respective blends with PCBM on device-relevant substrates. These polythiophenes exhibit different preferential orientation with respect to the surface from edge-on before and face-on after cleavage, explaining the observed swap in device performance.

Due to the mass-loss during cleavage, the relative amount of PCBM necessary to obtain solar cells with maximum efficiency is drastically reduced compared to non-cleavable polythiophenes like P3HT.

The compounds presented in this study show the potential of thermo-cleavable solubilizing side chains with controllable cleavage temperature. The moderate process temperature enables device fabrication on low-cost substrates. The reduced diffusivity of the polymers after cleavage enables the generation of morphologically more robust thin films which may lead to long-term stability of the morphology. Cleaving off the side chains and hence significantly reducing the material solubility makes this concept interesting for future multilayer organic optoelectronic devices, in particular when transferred to high-performance amorphous polymers.

\section{Acknowledgments}

The authors like to thank U.H.F. Bunz for measuring time on his analytical equipment as well as insightful discussions, BASF SE (T. Gessner \& T. Weitz) for TGA-MS-FTIR measurements and the Federal Ministry for Education and Research (BMBF) for funding under contract 13N11701 (project MORPHEUS). K.M. and T.M. acknowledge the ERC Advanced Grant NANOGRAPH (AdG-2010-267160). We also gratefully acknowledge the DELTA electron storage ring in Dortmund for providing synchrotron radiation and technical support in the GIWAXS measurements

\section{Supporting Information}


${ }^{1}$ Pron, A.; Gawrys, P.; Zagorska, M.; Djuradoa, D.; Demadrillea, R., Chem. Soc. Rev. 2010, 39, 2577-2632.

${ }^{2}$ Mei, J.; Bao, Z., Chem. Mater. 2014, 26, 604-615.

${ }^{3}$ Hotta, S.; Rughooputh, S. D. D. V.; Heeger, A. J.; Wudl, F., Macromolecules 1987, 20, 212-215.

${ }^{4}$ Mei, J.; Kim do, H.; Ayzner, A. L.; Toney, M.F.; Bao, Z., J. Am. Chem. Soc. 2011, 133, 20130-20133.

${ }^{5}$ Lei, T.; Dou, J.-H.; Pei, J., Adv. Mater. 2012, 24, 6457-6461.

${ }^{6}$ Lei, T.; Wang, J.-Y.; Pei, J., Chem. Mater. 2014, 26, 594-603.

${ }^{7}$ Li, W.; Wang, Q.; Ji Cui, H. C.; Shaheen, S. E.; Jabbour, G. E.; Anderson, J.; Lee, P.; Kippelen, B.; Peyghambarian, N.; Armstrong, N. R.; Marks, T. J., Adv. Mater. 1999, 11, 730-734.

${ }^{8}$ Bayerl, M. S.; Braig, T.; Nuyken, O.; Müller, D. C.; Groß, M.; Meerholz, K., Macromol. Rapid Commun. 1999, 20, 224-228.

${ }^{9}$ Huang, F.; Wu, H.; Cao, Y., Chem. Soc. Rev. 2010, 39, 2500-2521.

${ }^{10}$ Sax, S.; Rugen-Penkalla, N.; Neuhold, A.; Schuh, S.; Zojer, E.; List, E. J. W.; Müllen, K., Adv. Mater. 2010, 22 , 2087-2091.

${ }^{11}$ Liu, J.; Kadnikova, E. N.; Liu, Y.; McGehee, M. D.; Fréchet, J. M. J., J. Am. Chem. Soc. 2004, 126, 9486-9487.

${ }^{12}$ Bjerring, M.; Nielsen, J. S.; Nielsen, N. C.; Krebs, F. C., Macromolecules 2007, 40, 6012-6013.

${ }^{13} \mathrm{Yu}$, J.; Holdcroft, S., Macromolecules 2000, 33, 5073-5079.

${ }^{14}$ Petersen, M. H.; Gevorgyan, S. A.; Krebs, F. C., Macromolecules 2008, 41, 8986-8994.

${ }^{15}$ Hagemann, O.; Bjerring, M.; Nielsen, N. C.; Krebs, F. C., Sol. Energy Mater. Sol. Cells 2008, 92, 1327-1335.

${ }^{16}$ Krebs, F. C.; Spanggaard, H., Chem. Mater. 2005, 17, 5235-5237.

${ }^{17}$ Krebs, F. C.; Norrman, K., ACS Appl. Mater. Interfaces 2010, 2, 877-887.

${ }^{18}$ Rannard, S. P.; Davis, N. J., Org. Lett. 1999, 1, 933-936.

${ }^{19}$ Miyakoshi, R.; Yokoyama, A.; Yokozawa, T., J. Am. Chem. Soc. 2005, 127, 17542-17547.

${ }^{20}$ Xin, H.; Guo, X.; Kim, F. S.; Ren, G.; Watson, M. D.; Jenekhe, S. A., J. Mater. Chem. 2009, 19, 5303-5310.

${ }^{21}$ Speybroeck, V. V.; Martelé, Y.; Waroquier, M.; Schacht, E., J. Am. Chem. Soc. 2001, 123, 10650-10657.

${ }^{22}$ Speybroeck, V. V.; Martelé, Y.; Schacht, E.; Waroquier, M., J. Phys. Chem. A 2002, 106, 12370-12375.

${ }^{23}$ Søndergaard, R. R.; Norrman, K.; Krebs, F. C., J. Polym. Sci., Part A: Polym. Chem. 2012, 50, 1127-1132.

${ }^{24}$ Guo, X.; Puniredd, S. R.; Baumgarten, M.; Pisula, W.; Müllen, K., Adv. Mater. 2013, 25, 5467-5472.

${ }^{25}$ Joshi, S.; Pingel, P.; Grigorian, S.; Panzner, T.; Pietsch, U.; Neher, D.; Forster, M.; Scherf, U., Macromolecules 2009, 42, 4651-4660.

${ }^{26}$ Kline, R. J.; McGehee, M. D.; Kadnikova, E. N.; Liu, J.; Fréchet, J. M. J.; Toney, M. F., Macromolecules 2005, 38, 3312-3319.

${ }^{27}$ Rivnay, J.; Steyrleuthner, R.; Jimison, L. H.; Casadei, A.; Chen, Z.; Toney, M. F.; Facchetti, A.; Neher, D.; Salleo, A., Macromolecules 2011, 44, 5246-5255.

${ }^{28}$ Sirringhaus, H.; Brown, P. J.; Friend, R. H.; Nielsen, M. M.; Bechgaard, K.; Langeveld-Voss, B. M. W.; Spiering, A. J. H.; Janssen, R. A. J.; Meijer, E. W.; Herwig, P.; de Leeuw, D. M., Nature 1999, 401, (6754), 685-688.

${ }^{29}$ Chen, M. S.; Lee, O. P.; Niskala, J. R.; Yiu, A. T.; Tassone, C. J.; Schmidt, K.; Beaujuge, P. M.; Onishi, S. S.; Toney, M. F.; Zettl, A.; Fréchet, J. M. J., J. Am. Chem. Soc. 2013, 135, 19229-19236.

${ }^{30}$ Osaka, I.; Saito, M.; Mori, H.; Koganezawa, T.; Takimiya, K., Adv. Mater. 2012, 24, 425-430.

${ }^{31}$ Shao, M.; Keum, J.; Chen, J.; He, Y.; Chen, W.; Browning, J. F.; Jakowski, J.; Sumpter, B. G.; Ivanov, I. N.; Ma, Y.-Z.; Rouleau, C. M.; Smith, S. C.; Geohegan, D. B.; Hong, K.; Xiao, K., Nat. Commun. 2014, 5, 1-11.

${ }^{32}$ Verploegen, E.; Mondal, R.; Bettinger, C. J.; Sok, S.; Toney, M. F.; Bao, Z., Adv. Funct. Mater. 2010, 20, 35193529. 


\title{
Supporting Information
}

\section{Tertiary Carbonate Side Chains: Easily Tuneable Thermo- Labile Breaking Points for Controlling the Solubility of Conjugated Polymers}

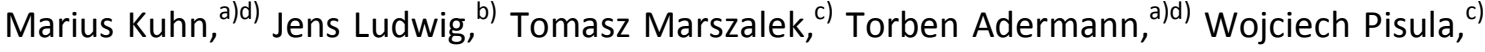 \\ Klaus Müllen, ${ }^{\text {c)d) }}$ Alexander Colsmann, ${ }^{\text {b) }}$ Manuel Hamburger ${ }^{\text {a)d }) *}$ \\ a) Institute of Organic Chemistry, Heidelberg University, Im Neuenheimer Feld 270, 69120 \\ Heidelberg, Germany \\ b) Light Technology Institute, Karlsruhe Institute of Technology (KIT), Engesserstr. 13, 76131 \\ Karlsruhe, Germany \\ c) Max Planck Institute for Polymer Research, Ackermannweg 10, 55128 Mainz, Germany \\ d) InnovationLab GmbH, Speyerer Str. 4, 69115 Heidelberg, Germany
}

\section{S1. Experimental.}

\section{General Remarks}

All reactions requiring exclusion of oxygen and moisture were carried out in dry glassware under a dry and oxygen free argon or nitrogen atmosphere. For spectroscopic and analytic characterizations the following devices were available:

Analytical Thin Layer Chromatography (TLC) was performed on Macherey-Nagel Polygram SIL G/UV 254 precoated sheets. Components were visualized by observation under UV irradiation (254 $\mathrm{nm}$ and $365 \mathrm{~nm}$ ) or with molybdophosphoric acid solution in ethanol.

Flash Column Chromatography was carried out on silica gel $(0.032 \mathrm{~mm}-0.062 \mathrm{~mm})$, purchased from Macherey, Nagel \& Co. 
DSC and TGA measurements were carried out on a Mettler-Toledo TGA/DSC1 instrument with a TGA/DSC-Sensor 1100 equipped with a MX1 balance (Mettler-Toledo) and a GC100 gas control box for nitrogen supply.

${ }^{1} \mathbf{H}$ NMR and ${ }^{13}$ C-NMR spectra were recorded at room temperature on Bruker Avance DRX $300(300 \mathrm{MHz})$ and Bruker Avance III $300(300 \mathrm{MHz})$. Chemical shifts $(\delta)$ are reported in parts per million (ppm) relative to residual undeuterated solvent peak. The following abbreviations are used to indicate the signal multiplicity: $s$ (singlet), $d$ (doublet), $t$ (triplet), $q$ (quartet), m (multiplet), dd (doublet of doublet), bs (broad singlet). All NMR spectra were integrated and processed using TopSpin 3.0.

High Resolution Mass Spectra (HR-MS) were determined at the Organisch-Chemisches Institut of the University of Heidelberg under the direction of Dr. J. Gross. All methods were recorded on a Vakuum Generators ZAB-2F $\left(\mathrm{EI}^{+}\right)$, Finnigan MAT TSQ $700\left(\mathrm{ESI}^{+}\right)$or JEOL JMS$700\left(\mathrm{FAB}^{+}\right)$spectrometer.

Infrared (IR) Spectra were recorded on a Jasco FT/IR-4100 spectrometer as neat oil or powder.

Absorption Spectra were carried out on a Jasco UV-VIS V-660 or Jasco UV-VIS V-670 in solution or in solid state via a spin-coated glass-slide.

Emission Spectra were recorded on a Jasco FP-6500 in solution or in solid state via a spincoated glass-slide.

Cyclic Voltammetry was performed with a VERSASTAT3-200 potentiostat (Princeton Applied Research) using a glassy carbon, gold or platin working electrode, a $0.1 \mathrm{~mol} / / \mathrm{Bu}_{4} \mathrm{~N}^{+} \mathrm{ClO}_{4}{ }^{-}$or $\mathrm{Bu}_{4} \mathrm{~N}^{+} \mathrm{PF}_{6}^{-}$solution in methylene chloride or THF as solvent and ferrocene/ferrocenium as reference redox system and internal or external standard.

Gel Permeation Chromatography was performed with Jasco intelligent RI- and UV/Visdetectors (RI-2031Plus, UV-2075Plus). Number- $\left(M_{n}\right)$ and weight average $\left(M_{w}\right)$ molecular weights and polydispersities (PDI) were determined by GPC versus polystyrene standards. Measurements were carried out at room temperature in chloroform (flow rate $1 \mathrm{~mL} / \mathrm{min}$ ) with PSS-SDV columns $\left(8.0 \mathrm{~mm} \times 30.0 \mathrm{~mm}, 5 \mu \mathrm{m}\right.$ particles, $10^{2}-, 10^{3}$ - and $10^{5}$ - $\AA$ pore size). All GPC traces were analyzed and processed by PSS WinGPC Unity Build 9350. 
Atomic Force Microscopy (AFM) measurements were performed on a Bruker Dimension ICON under inert conditions. Scan Asyst silicon nitride cantilevers from Bruker ( 70 kHz, 0.4 $\mathrm{N} / \mathrm{m}$ ) were used as sensors.

IUPAC names and atom numberings of the compounds described in the experimental section were determined with the program ACD/ChemScetch 2012 of Advanced Chemistry Development Inc.

Solvents were purchased from the store of the Theoretikum or chemical store at the Organisch-Chemisches Institut of the University of Heidelberg and if necessary distilled prior use. All of the other absolute solvents were dried by a MB SPS- 800 using drying columns.

Chemicals were either purchased from the chemical store at the Organisch-Chemisches Institut of the University of Heidelberg or from commercial laboratory suppliers. Reagents were used without further purification unless otherwise noted.

\section{Synthesis.}

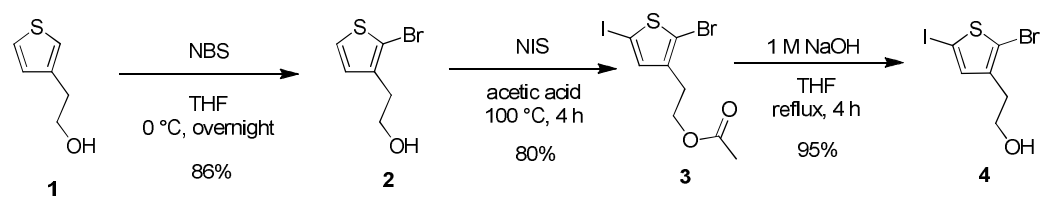

Scheme S1: Synthesis of 2-(2-Bromo-5-iodothiophen-3-yl)ethanol (4).

2-(2-Bromothiophen-3-yl)ethanol (2): $N$-bromosuccinimide (11.2 g, $62.5 \mathrm{mmol}, 1.00$ eq.) was added portionwise at $0{ }^{\circ} \mathrm{C}$ to a solution of 2-(thiophen-3-yl)ethanol (1) (8.02 g, 62.5 $\mathrm{mmol}, 1.00$ eq.) in tetrahydrofurane $(200 \mathrm{~mL})$, and the mixture was stirred at $0{ }^{\circ} \mathrm{C}$ overnight. The product was extracted with water and chloroform, washed with sodium hydrogen carbonate solution, and dried over anhydrous $\mathrm{MgSO}_{4}$. The crude product was further purified by column chromatography using petroleum ether/ethyl acetat $2: 1$ as the eluent to give a yellow oil (11.1 g, 86\%). $-{ }^{1} \mathrm{H}-\mathrm{NMR}\left(300 \mathrm{MHz}, \mathrm{CDCl}_{3}\right): \delta=7.26\left(\mathrm{~d},{ }^{3} \mathrm{~J}=5.6 \mathrm{~Hz}, 1 \mathrm{H}, H_{\mathrm{ar}}\right)$, $6.90\left(\mathrm{~d},{ }^{3} \mathrm{~J}=5.6 \mathrm{~Hz}, 1 \mathrm{H}, \mathrm{H}_{\mathrm{ar}}\right), 3.86\left(\mathrm{t},{ }^{3} \mathrm{~J}=6.6 \mathrm{~Hz}, 2 \mathrm{H}, \mathrm{CH}_{2}-\mathrm{OH}\right), 2.89\left(\mathrm{t},{ }^{3} \mathrm{~J}=6.6 \mathrm{~Hz}, 2 \mathrm{H}, \mathrm{C}_{\mathrm{ar}^{-}}\right.$ $\left.\mathrm{CH}_{2}\right), 1.75(\mathrm{~s}, 1 \mathrm{H}, \mathrm{OH}) .-{ }^{13} \mathrm{C}-\mathrm{NMR}\left(75 \mathrm{MHz}, \mathrm{CDCl}_{3}\right): \delta=138.1\left(\mathrm{C}_{\mathrm{ar}}-\mathrm{CH}_{2}\right), 128.7\left(C_{\mathrm{ar}}\right), 125.8\left(C_{\mathrm{ar}}\right)$, 


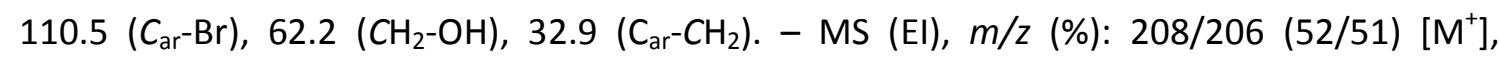
177/175 (100/91) [( $\left.\left.\mathrm{C}_{5} \mathrm{H}_{4} \mathrm{BrS}\right)^{+}\right], 97$ (38). - HRMS ( $\mathrm{C}_{6} \mathrm{H}_{7}$ BrOS): ber. 205.9401, gef. 205.9402.

2-(2-Bromo-5-iodothiophen-3-yl)ethyl acetate (3): 2-(2-Bromothiophen-3-yl)ethanol (2) (9.11 g, $44.0 \mathrm{mmol}, 1.00$ eq.) was dissolved in acetic acid $(50 \mathrm{~mL})$. After addition of $N$ iodosuccinimide (10.4 g, $46.2 \mathrm{mmol}, 1.05$ eq.) the resulting suspension was stirred at $100{ }^{\circ} \mathrm{C}$ for $4 \mathrm{~h}$. Then the mixture was poured into water and the organic layer was taken off while the water phase was extracted with dichloromethane. The combined organic phases were washed with $1 \mathrm{M}$ sodium hydroxide solution, $10 \%$ sodium thiosulfate solution water, brine and were dried over $\mathrm{MgSO}_{4}$. The crude product was further purified by column chromatography using petroleum ether/ethyl acetat 3:1 as the eluent to give a orange oil (15.4 g, 93\%). - ${ }^{1} \mathrm{H}-\mathrm{NMR}\left(300 \mathrm{MHz}, \mathrm{CDCl}_{3}\right): \delta=7.01\left(\mathrm{~s}, 1 \mathrm{H}, \mathrm{Har}_{\mathrm{ar}}\right), 4.20\left(\mathrm{t},{ }^{3} \mathrm{~J}=6.9 \mathrm{~Hz}, 2 \mathrm{H}, \mathrm{CH}_{2^{-}}\right.$ O), $2.88\left(\mathrm{t},{ }^{3} \mathrm{~J}=6.9 \mathrm{~Hz}, 2 \mathrm{H}, \mathrm{C}_{\mathrm{ar}}-\mathrm{CH}_{2}\right) 2.05\left(\mathrm{~s}, 3 \mathrm{H}, \mathrm{CH}_{3}\right) .-{ }^{13} \mathrm{C}-\mathrm{NMR}\left(75 \mathrm{MHz}, \mathrm{CDCl}_{3}\right): \delta=171.0$ $(C=0), 140.0\left(C_{\mathrm{ar}}-\mathrm{CH}_{2}\right), 138.1\left(\mathrm{C}_{\mathrm{ar}}\right), 113.7\left(\mathrm{Car}_{\mathrm{ar}} \mathrm{Br}\right), 71.7\left(\mathrm{Car}_{\mathrm{ar}} \mathrm{l}\right), 63.2\left(\mathrm{CH}_{2}-\mathrm{O}\right), 28.8\left(\mathrm{C}_{\mathrm{ar}}-\mathrm{CH}_{2}\right), 21.2$

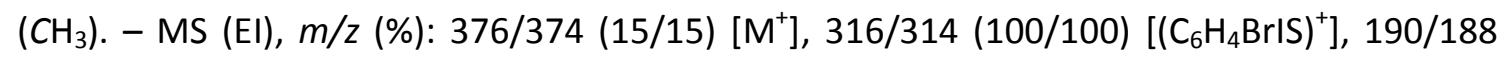
(8/9) $\left[\left(\mathrm{C}_{6} \mathrm{H}_{5} \mathrm{BrS}\right)^{+}\right]$. - HRMS $\left(\mathrm{C}_{8} \mathrm{H}_{8} \mathrm{BrIO}_{2} \mathrm{~S}\right)$ : ber. 373.8473 , gef. 373.8463 .

2-(2-Bromo-5-iodothiophen-3-yl)ethanol (4): 2-(2-Bromo-5-iodothiophen-3-yl)ethyl acetate (3) $(17.1 \mathrm{~g}, 45.7 \mathrm{mmol}, 1.00$ eq.) was dissolved into $350 \mathrm{~mL}$ of THF and $200 \mathrm{~mL}$ of $1 \mathrm{M}$ sodium hydroxide solution and stirred at $70{ }^{\circ} \mathrm{C}$ for $4 \mathrm{~h}$. The mixture was diluted with toluene and washed several times with water, dried over $\mathrm{MgSO}_{4}$, filtered and concentrated to give a colorless solid (14.9 g, 98\%). - ${ }^{1} \mathrm{H}-\mathrm{NMR}\left(300 \mathrm{MHz}, \mathrm{CDCl}_{3}\right): \delta=7.06\left(\mathrm{~s}, 1 \mathrm{H}, \mathrm{H}_{\mathrm{ar}}\right), 3.82\left(\mathrm{t},{ }^{3} \mathrm{~J}=6.4\right.$ $\left.\mathrm{Hz}, 2 \mathrm{H}, \mathrm{CH}_{2}-\mathrm{OH}\right), 2.82\left(\mathrm{t},{ }^{3} \mathrm{~J}=6.4 \mathrm{~Hz}, 2 \mathrm{H}, \mathrm{C}_{\mathrm{ar}}-\mathrm{CH}_{2}\right), 1.44(\mathrm{~s}, 1 \mathrm{H}, \mathrm{OH}) .-{ }^{13} \mathrm{C}-\mathrm{NMR}(75 \mathrm{MHz}$, $\left.\mathrm{CDCl}_{3}\right): \delta=140.5\left(\mathrm{C}_{\mathrm{ar}}-\mathrm{CH}_{2}\right), 138.4\left(\mathrm{C}_{\mathrm{ar}}\right), 113.4\left(\mathrm{Car}_{\mathrm{ar}} \mathrm{Br}\right), 71.8\left(\mathrm{Car}^{-1}\right), 62.0\left(\mathrm{CH}_{2}-\mathrm{OH}\right), 32.7\left(\mathrm{C}_{\mathrm{ar}}{ }^{-}\right.$ $\mathrm{CH}_{2}$ ). - MS (EI), m/z (\%): 334/332 (91/94) [ $\left.\mathrm{M}^{+}\right], 303 / 301$ (100/99) [( $\left.\left.\mathrm{C}_{5} \mathrm{H}_{3} \mathrm{BrIS}\right)^{+}\right] .-\mathrm{HRMS}$ $\left(\mathrm{C}_{6} \mathrm{H}_{6} \mathrm{BrIOS}\right)$ : ber. 331.8367, gef. 331.8363.

Table S1: Overview of the tertiary alcohols used in this study.

\begin{tabular}{|l|l|l|c|c|}
\hline Entry & & Alcohol & $\begin{array}{l}\text { Preparation } \\
\text { method }\end{array}$ & Yield [\%] \\
\hline 1 & $6 a$ & Ho & $-{ }^{a}$ & - \\
\hline
\end{tabular}




\begin{tabular}{|c|c|c|c|c|}
\hline 2 & $6 b$ & & $-^{\mathrm{a}}$ & - \\
\hline 3 & $6 c$ & & A & 70 \\
\hline 4 & $6 d$ & & A & 45 \\
\hline 5 & $6 e$ & & B & 78 \\
\hline 6 & $6 f$ & & B & 91 \\
\hline 7 & $6 g$ & & B & 78 \\
\hline 8 & $6 \mathrm{~h}$ & & A & 63 \\
\hline 9 & $6 i$ & & A & 94 \\
\hline 10 & $6 j$ & & $A$ & 100 \\
\hline
\end{tabular}

${ }^{\mathrm{a}}$ Commercially available.

1-Butylcyclopentanol (6c): $1.6 \mathrm{M}$ butyllithium in hexane $(31.3 \mathrm{~mL}, 3.20 \mathrm{~g}, 50.0 \mathrm{mmol}, 1.00$ eq.) was added to a solution of cyclopentanone $(4.21 \mathrm{~g}, 50.0 \mathrm{mmol}, 1.00 \mathrm{eq}$.) in the presence of $0.6 \mathrm{M}$ lanthanum chloride bis(lithium chloride) complex $(40.0 \mathrm{~mL}, 4.13 \mathrm{~g}, 12.5 \mathrm{mmol}, 0.25$ eq.) in tetrahydrofurane at $-78{ }^{\circ} \mathrm{C}$. The reaction mixture was left to warm up to room temperature. After $18 \mathrm{~h}$, ammonium chloride solution $(2 \mathrm{~mL})$ was added and the aqueous layer was extracted with diethyl ether. The combined extracts were dried over $\mathrm{Na}_{2} \mathrm{SO}_{4}$ and concentrated. The crude product was further purified by column chromatography using petroleum ether/ethyl acetat $10: 1$ as the eluent to give a yellow liquid $(5.46 \mathrm{~g}, 70 \%) .-{ }^{1} \mathrm{H}$ NMR $\left(300 \mathrm{MHz}, \mathrm{CDCl}_{3}\right): \delta=1.74-1.86\left(\mathrm{~m}, 3 \mathrm{H}, \mathrm{OH}+\mathrm{CH}_{2}\right), 1.52-1.66\left(\mathrm{~m}, 8 \mathrm{H}, 4 \times \mathrm{CH}_{2}\right), 1.26-$ $1.43\left(\mathrm{~m}, 4 \mathrm{H}, 2 \times \mathrm{CH}_{2}\right), 0.91\left(\mathrm{t},{ }^{3} \mathrm{~J}=7.0 \mathrm{~Hz}, 3 \mathrm{H}, \mathrm{CH}_{3}\right) .{ }^{13} \mathrm{C}-\mathrm{NMR}\left(75 \mathrm{MHz}, \mathrm{CDCl}_{3}\right): \delta=82.7\left(\mathrm{C}_{\mathrm{q}^{-}}\right.$ $\mathrm{OH}), 41.4\left(\mathrm{CH}_{2}\right), 39.8\left(2 \times \mathrm{CH}_{2}\right), 27.1\left(\mathrm{CH}_{2}\right), 24.0\left(2 \times \mathrm{CH}_{2}\right), 23.5\left(\mathrm{CH}_{2}\right), 14.3\left(\mathrm{CH}_{3}\right) .-\mathrm{FTIR}: \tilde{v}=$ 3376, 2954, 2871, 1696, 1634, $988 \mathrm{~cm}^{-1}$. - MS (EI), m/z (\%): $142(6)\left[\mathrm{M}^{+}\right], 113(57)\left[\left(\mathrm{C}_{7} \mathrm{H}_{13} \mathrm{O}\right)^{+}\right]$, $110(23)\left[\left(\mathrm{C}_{7} \mathrm{H}_{13} \mathrm{O}\right)^{+}\right], 85(100)\left[\left(\mathrm{C}_{5} \mathrm{H}_{9} \mathrm{O}\right)^{+}\right], 85(100)\left[\left(\mathrm{C}_{5} \mathrm{H}_{9} \mathrm{O}\right)^{+}\right], 58(29)$. - HRMS $\left(\mathrm{C}_{9} \mathrm{H}_{18} \mathrm{O}\right)$ : ber. 142.1358, gef. 142.1345 . 
1-Pentylcyclopentanol (6d): Pentylmagnesium bromide (38.6 g, $200 \mathrm{mmol}, 1.10$ eq.) in diethyl ether $(100 \mathrm{~mL})$ was added slowly to a solution, cooled to $0{ }^{\circ} \mathrm{C}$, of cyclopentanone (15.3 g, $182 \mathrm{mmol}, 1.00$ eq.) in diethyl ether $(200 \mathrm{~mL})$. The reaction mixture was stirred at room temperature overnight. The mixture was cooled to $0{ }^{\circ} \mathrm{C}$ again, quenched with ammonium sulfate solution $(200 \mathrm{~mL})$, washed with water and brine and dried over $\mathrm{MgSO}_{4}$, filtered and concentrated. The crude product was further purified by column chromatography using petroleum ether/ethyl acetat $10: 1$ as the eluent to give a yellow liquid (12.7 g, 45\%). $-{ }^{1} \mathrm{H}-\mathrm{NMR}\left(300 \mathrm{MHz}, \mathrm{CDCl}_{3}\right): \delta=1.69-1.85\left(\mathrm{~m}, 3 \mathrm{H}, \mathrm{OH}+\mathrm{CH}_{2}\right), 1.53-1.64$ $\left(\mathrm{m}, 8 \mathrm{H}, 4 \times \mathrm{CH}_{2}\right), 1.23-1.43\left(\mathrm{~m}, 6 \mathrm{H}, 3 \times \mathrm{CH}_{2}\right), 0.88\left(\mathrm{t},{ }^{3} \mathrm{~J}=6.7 \mathrm{~Hz}, 3 \mathrm{H}, \mathrm{CH}_{3}\right) .-{ }^{13} \mathrm{C}-\mathrm{NMR}(75$ $\left.\mathrm{MHz}, \mathrm{CDCl}_{3}\right): \delta=82.7\left(\mathrm{C}_{\mathrm{q}} \mathrm{-OH}\right), 41.6\left(\mathrm{CH}_{2}\right), 39.8\left(2 \times \mathrm{CH}_{2}\right), 32.6\left(\mathrm{CH}_{2}\right), 24.5\left(\mathrm{CH}_{2}\right), 24.0(2 \times$ $\left.\mathrm{CH}_{2}\right), 22.9\left(\mathrm{CH}_{2}\right), 14.2\left(\mathrm{CH}_{3}\right)$. - FTIR: $\tilde{v}=3384,2954,2872,1697,1632,1455,1001 \mathrm{~cm}^{-1} .-\mathrm{MS}$ (EI), m/z (\%): $156(4)\left[\mathrm{M}^{+}\right], 127(31)\left[\left(\mathrm{C}_{8} \mathrm{H}_{15} \mathrm{O}\right)^{+}\right], 113(29)\left[\left(\mathrm{C}_{7} \mathrm{H}_{13} \mathrm{O}\right)^{+}\right], 99(23)\left[\left(\mathrm{C}_{6} \mathrm{H}_{11} \mathrm{O}\right)^{+}\right], 85$ (100) $\left[\left(\mathrm{C}_{5} \mathrm{H}_{9} \mathrm{O}\right)^{+}\right], 67(32), 58(34)$. $-\mathrm{HRMS}\left(\mathrm{C}_{10} \mathrm{H}_{20} \mathrm{O}\right)$ : ber. 156.1514, gef. 156.1531.

2-Methyloct-3-yn-2-ol (6e): To a solution of 1-hexyne (4.11 g, $50.0 \mathrm{mmol}, 1.00$ eq.) in tetrahydrofurane $(50 \mathrm{~mL})$ was added $1.6 \mathrm{M}$ butyllithium in hexane $(34.4 \mathrm{~mL}, 3.52 \mathrm{~g}, 55.0$ mmol, 1.10 eq.) at $-78^{\circ} \mathrm{C}$. The reaction mixture was stirred for 1 hour at this temperature, then the solution was left to warm to room temperature. After that period the reaction mixture was cooled down to $-78{ }^{\circ} \mathrm{C}$ again and then acetone $(3.49 \mathrm{~g}, 60.0 \mathrm{mmol}, 1.20 \mathrm{eq}$.) was added. The reaction mixture was left to warm up to room temperature and stirred overnight. The reaction mixture was quenched with water $(20 \mathrm{~mL})$ and washed three times with water. The organic layer was collected and dried over anhydrous $\mathrm{MgSO}_{4}$. After filtration, the organic solvent was removed by evaporation under reduced pressure. The crude product was further purified by column chromatography using petroleum ether/ethyl acetat $10: 1$ as the eluent to give a colorless liquid $(5.47 \mathrm{~g}, 78 \%) .-{ }^{1} \mathrm{H}-\mathrm{NMR}\left(300 \mathrm{MHz}, \mathrm{CDCl}_{3}\right)$ : $\delta=2.17\left(\mathrm{t},{ }^{3} \mathrm{~J}=6.9 \mathrm{~Hz}, 2 \mathrm{H}, \mathrm{CH}_{2}\right), 1.96(\mathrm{bs}, 1 \mathrm{H}, \mathrm{OH}), 1.32-1.52\left(\mathrm{~m}, 4 \mathrm{H}, 2 \times \mathrm{CH}_{2}\right), 1.48(\mathrm{~s}, 6 \mathrm{H}, 2$ $\left.\times \mathrm{CH}_{3}\right), 0.89\left(\mathrm{t},{ }^{3} \mathrm{~J}=7.0 \mathrm{~Hz}, 3 \mathrm{H}, \mathrm{CH}_{3}\right) \cdot-{ }^{13} \mathrm{C}-\mathrm{NMR}\left(75 \mathrm{MHz}, \mathrm{CDCl}_{3}\right): \delta=85.2\left(\mathrm{C}_{\mathrm{q}}-\mathrm{C}\right), 82.7\left(\mathrm{C}-\mathrm{CH}_{2}\right)$, $65.4\left(\mathrm{C}_{\mathrm{q}}-\mathrm{OH}\right), 31.9\left(2 \times \mathrm{CH}_{3}\right), 30.9\left(\mathrm{CH}_{2}\right), 22.0\left(\mathrm{CH}_{2}\right), 18.03\left(\mathrm{CH}_{2}\right), 13.7\left(\mathrm{CH}_{3}\right) .-\mathrm{FTIR}: \tilde{v}=3354$, 2978, 2934, 2871, 2235, 1462, 1362, 1238, 1163, 944, $554 \mathrm{~cm}^{-1}$. - MS (EI), m/z (\%): 140 (1) $\left[\mathrm{M}^{+}\right], 125(100)\left[\left(\mathrm{C}_{8} \mathrm{H}_{13} \mathrm{O}\right)^{+}\right], 43(100)\left[\left(\mathrm{C}_{3} \mathrm{H}_{7}\right)^{+}\right]$. - HRMS $\left(\mathrm{C}_{9} \mathrm{H}_{16} \mathrm{O}\right)$ : ber. 140.1201, gef. 140.1197 . 
1-(Hex-1-yn-1-yl)cyclohexanol (6f): To a solution of 1-hexyne (4.11 g, $50.0 \mathrm{mmol}, 1.00 \mathrm{eq}$.$) in$ tetrahydrofurane $(100 \mathrm{~mL})$ was added $1.6 \mathrm{M}$ butyllithium in hexane $(34.4 \mathrm{~mL}, 3.52 \mathrm{~g}, 55.0$ mmol, 1.10 eq.) at $-78{ }^{\circ} \mathrm{C}$. The reaction mixture was stirred for 1 hour at this temperature, then the solution was left to warm to room temperature. After that period the reaction mixture was cooled down to $-78{ }^{\circ} \mathrm{C}$ again and then cyclohexanone $(5.89 \mathrm{~g}, 60.0 \mathrm{mmol}, 1.20$ eq.) was added. The reaction mixture was left to warm up to room temperature and stirred overnight. The reaction mixture was quenched with water $(20 \mathrm{~mL})$ and washed three times with water. The organic layer was collected and dried over anhydrous MgSO4. After filtration, the organic solvent was removed by evaporation under reduced pressure. The crude product was further purified by column chromatography using petroleum ether/ethyl acetat 10:1 as the eluent to give a yellow liquid $(8.21 \mathrm{~g}, 91 \%) .-{ }^{1} \mathrm{H}-\mathrm{NMR}\left(300 \mathrm{MHz}, \mathrm{CDCl}_{3}\right): \delta$ $=2.21\left(\mathrm{t},{ }^{3} \mathrm{~J}=6.9 \mathrm{~Hz}, 2 \mathrm{H}, \mathrm{CH}_{2}\right), 1.80-1.91\left(\mathrm{~m}, 2 \mathrm{H}, \mathrm{CH}_{2}\right), 1.77(\mathrm{~s}, 1 \mathrm{H}, \mathrm{OH}), 1.60-1.72(\mathrm{~m}, 2 \mathrm{H}$, $\left.\mathrm{CH}_{2}\right), 1.23-1.58\left(\mathrm{~m}, 10 \mathrm{H}, 5 \times \mathrm{CH}_{2}\right), 0.90\left(\mathrm{t},{ }^{3} \mathrm{~J}=7.2 \mathrm{~Hz}, 3 \mathrm{H}, \mathrm{CH}_{3}\right) .-{ }^{13} \mathrm{C}-\mathrm{NMR}\left(75 \mathrm{MHz}, \mathrm{CDCl}_{3}\right): \delta$ $=84.8\left(\mathrm{C}_{\mathrm{q}}-\mathrm{C}\right), 84.0\left(\mathrm{C}-\mathrm{CH}_{2}\right), 68.9\left(\mathrm{C}_{\mathrm{q}}-\mathrm{OH}\right), 40.4\left(2 \times \mathrm{CH}_{2}\right), 31.0\left(\mathrm{CH}_{2}\right), 25.4\left(\mathrm{CH}_{2}\right), 23.6\left(2 \times \mathrm{CH}_{2}\right)$, $22.0\left(\mathrm{CH}_{2}\right), 18.5\left(\mathrm{CH}_{2}\right), 13.7\left(\mathrm{CH}_{3}\right) .-\mathrm{FTIR}: \tilde{v}=3362,2929,2859,1447,1061,963 \mathrm{~cm}^{-1} .-\mathrm{MS}$ (EI), $m / z(\%): 180(18)\left[\mathrm{M}^{+}\right], 137(100)\left[\left(\mathrm{C}_{9} \mathrm{H}_{13} \mathrm{O}\right)^{+}\right]$. - HRMS $\left(\mathrm{C}_{11} \mathrm{H}_{18} \mathrm{O}\right)$ : ber. 180.1514, gef. 180.1521.

1-(Hex-1-yn-1-yl)cyclopentanol (6g): To a solution of 1-hexyne (4.11 g, $50.0 \mathrm{mmol}, 1.00 \mathrm{eq}$. in tetrahydrofurane $(100 \mathrm{~mL})$ was added $1.6 \mathrm{M}$ butyllithium in hexane $(34.4 \mathrm{~mL}, 3.52 \mathrm{~g}, 55.0$ mmol, 1.10 eq.) at $-78{ }^{\circ} \mathrm{C}$. The reaction mixture was stirred for 1 hour at this temperature, then the solution was left to warm to room temperature. After that period the reaction mixture was cooled down to $-78{ }^{\circ} \mathrm{C}$ again and then cyclopentanone $(5.05 \mathrm{~g}, 60.0 \mathrm{mmol}, 1.20$ eq.) was added. The reaction mixture was left to warm up to room temperature and stirred overnight. The reaction mixture was quenched with water $(20 \mathrm{~mL})$ and washed three times with water. The organic layer was collected and dried over anhydrous $\mathrm{MgSO}_{4}$. After filtration, the organic solvent was removed by evaporation under reduced pressure. The crude product was further purified by column chromatography using petroleum ether/ethyl acetat $10: 1$ as the eluent to give a yellow liquid $(6.47 \mathrm{~g}, 78 \%) .-{ }^{1} \mathrm{H}-\mathrm{NMR}\left(300 \mathrm{MHz}, \mathrm{CDCl}_{3}\right): \delta$ $=2.19\left(\mathrm{t},{ }^{3} \mathrm{~J}=6.9 \mathrm{~Hz}, 2 \mathrm{H}, \mathrm{CH}_{2}\right), 1.64-1.89\left(\mathrm{~m}, 9 \mathrm{H}, \mathrm{OH}+4 \times \mathrm{CH}_{2}\right), 1.33-1.52\left(\mathrm{~m}, 4 \mathrm{H}, 2 \times \mathrm{CH}_{2}\right)$, $0.90\left(\mathrm{t},{ }^{3} \mathrm{~J}=7.1 \mathrm{~Hz}, 3 \mathrm{H}, \mathrm{CH}_{3}\right) .-{ }^{13} \mathrm{C}-\mathrm{NMR}\left(75 \mathrm{MHz}, \mathrm{CDCl}_{3}\right): \delta=84.1\left(\mathrm{C}_{\mathrm{q}}-\mathrm{C}\right), 83.7\left(\mathrm{C}-\mathrm{CH}_{2}\right), 74.9$ $\left(\mathrm{C}_{\mathrm{q}}-\mathrm{OH}\right), 42.8\left(2 \times \mathrm{CH}_{2}\right), 31.1\left(\mathrm{CH}_{2}\right), 23.5\left(2 \times \mathrm{CH}_{2}\right), 22.1\left(\mathrm{CH}_{2}\right), 18.5\left(\mathrm{CH}_{2}\right), 13.8\left(\mathrm{CH}_{3}\right) .-\mathrm{FTIR}: \tilde{\mathrm{v}}$

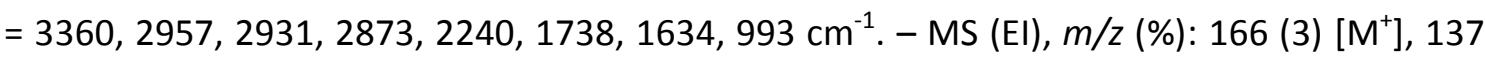


(100) $\left[\left(\mathrm{C}_{9} \mathrm{H}_{13} \mathrm{O}\right)^{+}\right], 124(22)\left[\left(\mathrm{C}_{8} \mathrm{H}_{12} \mathrm{O}\right)^{+}\right], 109(26)\left[\left(\mathrm{C}_{7} \mathrm{H}_{9} \mathrm{O}\right)^{+}\right] .-\mathrm{HRMS}\left(\mathrm{C}_{11} \mathrm{H}_{18} \mathrm{O}\right)$ : ber. 166.1358, gef. 166.1368 .

(E)-Methylhex-3-en-2-ol (6h): Methylmagnesium bromide (79.3 g, $300 \mathrm{mmol}, 2.20$ eq.) in diethyl ether $(100 \mathrm{~mL})$ was added slowly to a solution, cooled to $0{ }^{\circ} \mathrm{C}$, of $(E)$-methyl pent-2enoate $(15.4 \mathrm{~g}, 135 \mathrm{mmol}, 1.00$ eq.) in diethyl ether $(200 \mathrm{~mL})$. The reaction mixture was stirred at room temperature overnight. The mixture was cooled to $0{ }^{\circ} \mathrm{C}$ again, quenched with ammonium sulfate solution $\left(200 \mathrm{~mL}\right.$ ), washed with water and brine and dried over $\mathrm{MgSO}_{4}$, filtered and concentrated. The crude product was further purified by column chromatography using petroleum ether/ethyl acetat 10:1 as the eluent to give a colorless oil (9.72 g, 63\%). $-{ }^{1} \mathrm{H}-\mathrm{NMR}\left(300 \mathrm{MHz}, \mathrm{CDCl}_{3}\right): \delta=5.66\left(\mathrm{dt},{ }^{3} \mathrm{~J}=15.7 \mathrm{~Hz},{ }^{3} \mathrm{~J}=5.4 \mathrm{~Hz}, 1 \mathrm{H}, \mathrm{CH}-\mathrm{CH}_{2}\right)$, $5.58\left(\mathrm{~d},{ }^{3} \mathrm{~J}=15.7 \mathrm{~Hz}, 1 \mathrm{H}, \mathrm{C}_{\mathrm{q}}-\mathrm{CH}\right), 2.03\left(\mathrm{dq},{ }^{3} \mathrm{~J}=7.4 \mathrm{~Hz},{ }^{3} \mathrm{~J}=5.4 \mathrm{~Hz}, 2 \mathrm{H}, \mathrm{CH}_{2}\right), 1.43(\mathrm{bs}, 1 \mathrm{H}$, $\mathrm{OH}), 1.30\left(\mathrm{~s}, 6 \mathrm{H}, 2 \times \mathrm{CH}_{3}\right), 0.98\left(\mathrm{~d},{ }^{3} \mathrm{~J}=7.4 \mathrm{~Hz}, 3 \mathrm{H}, \mathrm{CH}_{3}\right) .-{ }^{13} \mathrm{C}-\mathrm{NMR}\left(75 \mathrm{MHz}, \mathrm{CDCl}_{3}\right): \delta=$ $137.0\left(\mathrm{C}_{\mathrm{q}}-\mathrm{CH}\right), 129.0\left(\mathrm{CH}-\mathrm{CH}_{2}\right), 70.7\left(\mathrm{HO}-\mathrm{C}_{\mathrm{q}}\right), 30.0\left(2 \times \mathrm{CH}_{3}\right), 25.3\left(\mathrm{CH}_{2}\right), 13.8\left(\mathrm{CH}_{3}\right) .-\mathrm{FTIR}: \tilde{\mathrm{v}}=$ $3354,2966,2932,2874,1461,1372,1361,1234,1147,968,908,797 \mathrm{~cm}^{-1}$. MS (EI), m/z (\%): $114(7)\left[\mathrm{M}^{+}\right], 99(51)\left[\left(\mathrm{C}_{6} \mathrm{H}_{11} \mathrm{O}\right)^{+}\right], 85(33), 59(24), 43(100)\left[\left(\mathrm{C}_{3} \mathrm{H}_{7}\right)^{+}\right] .-\operatorname{HRMS}\left(\mathrm{C}_{7} \mathrm{H}_{14} \mathrm{O}\right)$ : ber. 114.1045, gef. 114.1061 .

(E)-2-Methyloct-3-en-2-ol (6i): Methylmagnesium bromide (79.3 g, $300 \mathrm{mmol}, 1.10$ eq.) in diethyl ether $(100 \mathrm{~mL})$ was added slowly to a solution, cooled to $0{ }^{\circ} \mathrm{C}$, of $(E)$-oct-3-en-2-one (34.3 g, $272 \mathrm{mmol}, 1.00$ eq.) in diethyl ether $(250 \mathrm{~mL})$. The reaction mixture was stirred at room temperature overnight. The mixture was cooled to $0{ }^{\circ} \mathrm{C}$ again, quenched with ammonium sulfate solution $\left(200 \mathrm{~mL}\right.$ ), washed with water and brine and dried over $\mathrm{MgSO}_{4}$, filtered and concentrated. The crude product was further purified by column chromatography using petroleum ether/ethyl acetat 5:1 as the eluent to give a yellow oil (29.1 g, 94\%). $-{ }^{1} \mathrm{H}-\mathrm{NMR}\left(300 \mathrm{MHz}, \mathrm{CDCl}_{3}\right): \delta=5.55-5.67\left(\mathrm{~m}, 2 \mathrm{H}, \mathrm{CH}-\mathrm{CH}_{2}+\mathrm{C}_{\mathrm{q}}-\mathrm{CH}\right), 1.98-2.04$ $\left(\mathrm{m}, 2 \mathrm{H}, \mathrm{CH}_{2}\right), 1.37$ (bs, $\left.1 \mathrm{H}, \mathrm{OH}\right), 1.25-1.35\left(\mathrm{~m}, 4 \mathrm{H}, 2 \times \mathrm{CH}_{2}\right), 1.30\left(\mathrm{~s}, 6 \mathrm{H}, 2 \times \mathrm{CH}_{3}\right), 0.89\left(\mathrm{t},{ }^{3} \mathrm{~J}\right.$ $\left.=7.0 \mathrm{~Hz}, 3 \mathrm{H}, \mathrm{CH}_{3}\right) .-{ }^{13} \mathrm{C}-\mathrm{NMR}\left(75 \mathrm{MHz}, \mathrm{CDCl}_{3}\right): \delta=138.1\left(\mathrm{C}_{\mathrm{q}}-\mathrm{CH}\right), 127.5\left(\mathrm{CH}^{-} \mathrm{CH}_{2}\right), 70.8(\mathrm{HO}-$ $\left.C_{\mathrm{q}}\right), 32.0\left(\mathrm{CH}_{2}\right), 31.6\left(\mathrm{CH}_{2}\right), 30.0\left(2 \times \mathrm{CH}_{3}\right), 22.4\left(\mathrm{CH}_{2}\right), 14.1\left(\mathrm{CH}_{3}\right) .-$ FTIR: $\tilde{v}=3358,2960,2923$, 2859, 1464, 1376, 1148, 969, $902 \mathrm{~cm}^{-1}$. MS (EI), $m / z(\%): 142(9)\left[\mathrm{M}^{+}\right], 127(51)\left[\left(\mathrm{C}_{8} \mathrm{H}_{15} \mathrm{O}\right)^{+}\right]$, 85 (59), $71(100)\left[\left(\mathrm{C}_{5} \mathrm{H}_{11}\right)^{+}\right]$. - HRMS $\left(\mathrm{C}_{9} \mathrm{H}_{18} \mathrm{O}\right)$ : ber. 142.1358, gef. 142.1362.

2-(3,5-Dimethylphenyl)propan-2-ol (6j): $3.0 \mathrm{M}$ Methylmagnesium bromide (18.2 g, 68.8 mmol, 2.20 eq.) in diethyl ether $(23 \mathrm{~mL})$ was added slowly to a solution, cooled to $0{ }^{\circ} \mathrm{C}$, of 
methyl 3,5-dimethylbenzoate $(5.09 \mathrm{~g}, 31.0 \mathrm{mmol}, 1.00$ eq.) in diethyl ether (150 mL). The reaction mixture was stirred at room temperature overnight. The mixture was cooled to $0{ }^{\circ} \mathrm{C}$ again, quenched with ammonium sulfate solution $(200 \mathrm{~mL})$, washed with water and brine and dried over $\mathrm{MgSO}_{4}$, filtered and concentrated. The crude product was further purified by column chromatography using petroleum ether/ethyl acetat 10:1 as the eluent to give a colorless oil (5.10 g, quant.). $-{ }^{1} \mathrm{H}-\mathrm{NMR}\left(300 \mathrm{MHz}, \mathrm{CDCl}_{3}\right): \delta=7.12\left(\mathrm{~s}, 2 \mathrm{H}, 2 \times \mathrm{C}_{\mathrm{ar}} \mathrm{H}\right), 0.94(\mathrm{~s}, 1$ $\left.\mathrm{H}, \mathrm{C}_{\mathrm{ar}} \mathrm{H}\right), 2.35\left(\mathrm{~s}, 6 \mathrm{H}, 2 \times \mathrm{C}_{\mathrm{ar}}-\mathrm{CH}_{3}\right), 1.84(\mathrm{~s}, 1 \mathrm{H}, \mathrm{OH}), 1.58\left(\mathrm{~s}, 6 \mathrm{H}, 2 \times \mathrm{C}_{\mathrm{q}}-\mathrm{CH}_{3}\right) .-{ }^{13} \mathrm{C}-\mathrm{NMR}(75$ $\left.\mathrm{MHz}, \mathrm{CDCl}_{3}\right): \delta=149.3\left(\mathrm{Car}^{-} \mathrm{C}_{\mathrm{q}}\right), 137.9\left(2 \times \mathrm{Car}^{-} \mathrm{CH}_{3}\right), 128.5\left(\mathrm{Car}_{\mathrm{ar}} \mathrm{H}\right), 122.3\left(2 \times \mathrm{C}_{\mathrm{ar}} \mathrm{H}\right), 72.6\left(\mathrm{C}_{\mathrm{q}^{-}}\right.$ $\mathrm{OH}), 31.9\left(2 \times \mathrm{C}_{\mathrm{q}}-\mathrm{CH}_{3}\right), 21.6\left(2 \times \mathrm{C}_{\mathrm{ar}}-\mathrm{CH}_{3}\right) .-\mathrm{FTIR}: \tilde{\mathrm{v}}=3388,2975,2918,2867,1727,1603$, 1451, 1363, 1159, 938, 848, 809, $706 \mathrm{~cm}^{-1}$. - MS (EI), m/z (\%): 164 (48) [M+1, 149 (100) $\left[\left(\mathrm{C}_{10} \mathrm{H}_{13} \mathrm{O}\right)^{+}\right]$. - HRMS $\left(\mathrm{C}_{11} \mathrm{H}_{16} \mathrm{O}\right)$ : ber. 164.1201, gef. 164.1185.
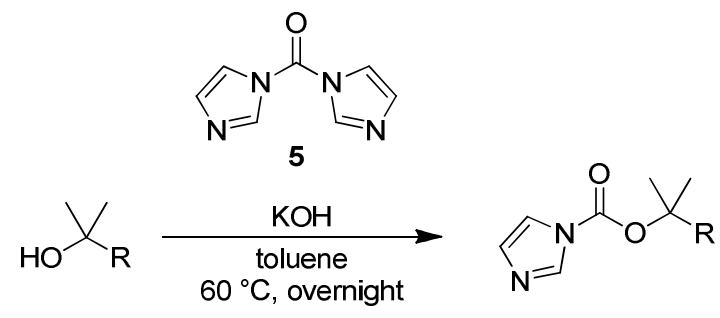

$6 \mathbf{a}-\mathbf{j}$

$7 a-j$

Scheme S2: Synthesis of imidazole- $N$-carboxylic esters $7 a-j$.

Table S2: Overview of the imidazole- $N$-carboxylic $7 a-j$ esters prepared in this study.

\begin{tabular}{|l|l|l|c|}
\hline Entry & & Product & Yield [\%] \\
\hline 1 & $7 \mathrm{a}$ & 86 \\
\hline $\mathbf{2}$ & $7 \mathrm{~b}$ & \\
\hline 3 & $7 \mathrm{c}$ & & \\
\hline & & & 31 \\
\hline
\end{tabular}




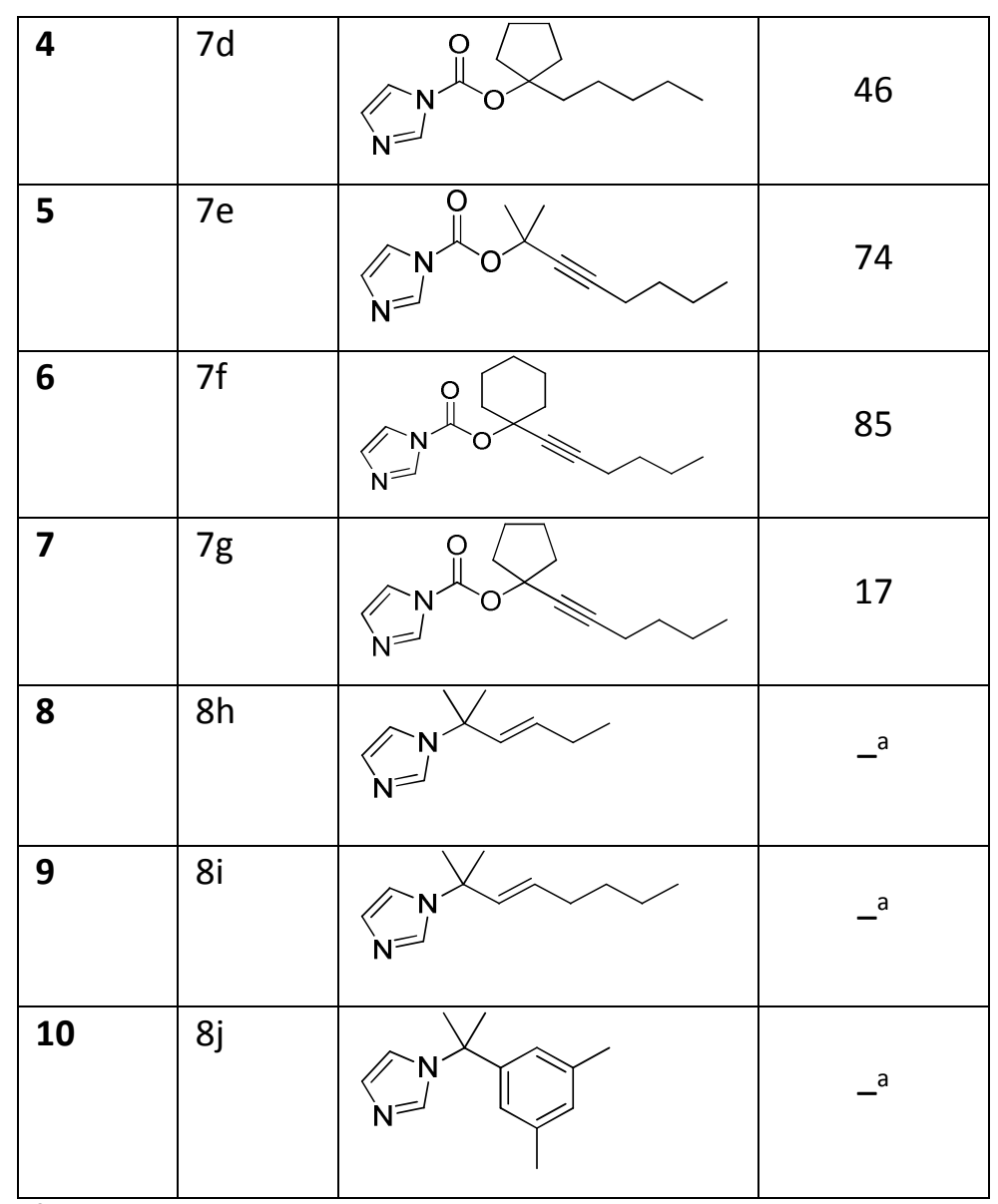

${ }^{a}$ No imidazole- $N$-carboxylic esters found.

General procedure A for synthesis of imidazole-N-carboxylic esters 7: To a solution of 1,1carbonyldiimidazole (5) (1.10 eq.) in toluene $(5.0 \mathrm{~mL} / \mathrm{mmol})$, alcohol $6 a-j$ (1.00 eq.) and potassium hydroxide (0.01 eq.) was added. The reaction mixture was stirred at $60{ }^{\circ} \mathrm{C}$ overnight. The solution was left to cool and concentrated in vacuo. The residue was dissolved in dichloromethane and washed three times with water. The organic layer was collected and dried over anhydrous $\mathrm{MgSO}_{4}$. After filtration, the organic solvent was removed by evaporation under reduced pressure. The crude product was further purified by column chromatography using mixtures of petroleum ether/ethyl acetat as the eluent to give the imidazole- $N$-carboxylic esters $7 \mathbf{a}-\mathbf{g}$.

2-Methylhexan-2-yl 1H-imidazole-1-carboxylate (7a): The reaction was carried out with 1,1carbonyldiimidazole (5) (19.6 g, 110 mmol, 1.10 eq.), 2-methylhexan-2-ol (6a) (11.6 g, 100 mmol, 1.00 eq.) and potassium hydroxide $(55.0 \mathrm{mg}, 1.00 \mathrm{mmol}, 0.01$ eq.) according to general procedure A. The crude product was further purified by column chromatography 
using petroleum ether/ethyl acetat 5:1 as the eluent to give a colorless liquid (18.0 g, 86\%).${ }^{1} \mathrm{H}-\mathrm{NMR}\left(300 \mathrm{MHz}, \mathrm{CDCl}_{3}\right): \delta=8.04\left(\mathrm{~s}, 1 \mathrm{H}, H_{\mathrm{ar}}\right), 7.34\left(\mathrm{~s}, 1 \mathrm{H}, H_{\mathrm{ar}}\right), 7.01\left(\mathrm{~s}, 1 \mathrm{H}, H_{\mathrm{ar}}\right), 1.83-1.89$ $\left(\mathrm{m}, 2 \mathrm{H}, \mathrm{CH}_{2}\right), 1.58\left(\mathrm{~s}, 6 \mathrm{H}, 2 \times \mathrm{CH}_{3}\right), 1.30-1.38\left(\mathrm{~m}, 4 \mathrm{H}, 2 \times \mathrm{CH}_{2}\right), 0.89-0.92\left(\mathrm{~m}, 3 \mathrm{H}, \mathrm{CH}_{3}\right) .-$ ${ }^{13} \mathrm{C}-\mathrm{NMR}\left(75 \mathrm{MHz}, \mathrm{CDCl}_{3}\right): \delta=147.1(C=\mathrm{O}), 137.2\left(C_{\mathrm{ar}} \mathrm{H}\right), 130.4\left(C_{\mathrm{ar}} \mathrm{H}\right), 117.2\left(C_{\mathrm{ar}} \mathrm{H}\right), 88.1(\mathrm{O}-$ $\left.C_{q}\right)$, $40.6\left(\mathrm{CH}_{2}\right), 26.2\left(\mathrm{CH}_{2}\right), 25.9\left(2 \times \mathrm{CH}_{3}\right), 22.6\left(\mathrm{CH}_{2}\right), 14.0\left(\mathrm{CH}_{3}\right) .-\mathrm{FTIR}: \tilde{\mathrm{v}}=2958,2934,2871$, $1754,1470,1379,1319,1285,1241,1218,1182,1149,1092,1057,855,836,772,763,650$, $599 \mathrm{~cm}^{-1}$. - MS (EI), m/z (\%): $210(10)\left[\mathrm{M}^{+}\right], 153(18)\left[\left(\mathrm{C}_{7} \mathrm{H}_{9} \mathrm{~N}_{2} \mathrm{O}_{2}\right)^{+}\right], 99(100)\left[\left(\mathrm{C}_{7} \mathrm{H}_{15}\right)^{+}\right], 95(45)$ $\left[\left(\mathrm{C}_{4} \mathrm{H}_{3} \mathrm{~N}_{2} \mathrm{O}\right)^{+}\right]$. - HRMS $\left(\mathrm{C}_{11} \mathrm{H}_{18} \mathrm{~N}_{2} \mathrm{O}_{2}\right)$ : ber. 210.1368, gef. 210.1355 .

1-Methylcyclohexyl $\mathbf{1 H}$-imidazole-1-carboxylate (7b): The reaction was carried out with 1,1carbonyldiimidazole (5) (11.8 g, $66.0 \mathrm{mmol}, 1.10$ eq.), 1-methylcyclohexanol (6b) (6.85 g, $60.0 \mathrm{mmol}, 1.00$ eq.) and potassium hydroxide (34.0 mg, $600 \mu \mathrm{mol}, 0.01$ eq.) according to general procedure $\mathbf{A}$. The crude product was further purified by column chromatography using petroleum ether/ethyl acetat 3:1 as the eluent to give a colorless solid ( $7.83 \mathrm{~g}, 63 \%)$. ${ }^{1} \mathrm{H}-\mathrm{NMR}\left(300 \mathrm{MHz}, \mathrm{CDCl}_{3}\right): \delta=8.07\left(\mathrm{~s}, 1 \mathrm{H}, H_{\mathrm{ar}}\right), 7.36\left(\mathrm{~s}, 1 \mathrm{H}, H_{\mathrm{ar}}\right), 7.01\left(\mathrm{~s}, 1 \mathrm{H}, H_{\mathrm{ar}}\right), 2.20-2.30$ $\left(\mathrm{m}, 2 \mathrm{H}, \mathrm{CH}_{2}\right), 1.25-1.63\left(\mathrm{~m}, 8 \mathrm{H}, 4 \times \mathrm{CH}_{2}\right), 1.60\left(\mathrm{~s}, 3 \mathrm{H}, \mathrm{CH}_{3}\right) .-{ }^{13} \mathrm{C}-\mathrm{NMR}\left(75 \mathrm{MHz}, \mathrm{CDCl}_{3}\right): \delta=$ $147.0(C=0), 137.1\left(C_{a r} H\right), 130.4\left(C_{a r} H\right), 117.1\left(C_{a r} H\right), 87.3\left(\mathrm{O}-C_{q}\right), 36.5\left(2 \times C_{2}\right), 25.4\left(C_{2}\right)$, $25.1\left(\mathrm{CH}_{3}\right), 22.2\left(2 \times \mathrm{CH}_{2}\right) .-$ FTIR: $\tilde{v}=2933,2862,1748,1469,1447,1378,1318,1298,1275$, $1231,1182,1146,1092,1058,1000,960,867,832,770,744,651,484 \mathrm{~cm}^{-1}$. MS (EI), m/z (\%): $208(2)\left[\mathrm{M}^{+}\right], 97(52)\left[\left(\mathrm{C}_{7} \mathrm{H}_{13}\right)^{+}\right], 81$ (100). - HRMS $\left(\mathrm{C}_{11} \mathrm{H}_{16} \mathrm{~N}_{2} \mathrm{O}_{2}\right)$ : ber. 208.1212, gef. 208.1238 .

1-Butylcyclopentyl $\mathbf{1 H}$-imidazole-1-carboxylate (7c): The reaction was carried out with 1,1carbonyldiimidazole (5) (7.09 g, $35.0 \mathrm{mmol}, 1.10$ eq.), 1-butylcyclopentanol (6c) (3.98 g, 28.0 mmol, 1.00 eq.) and potassium hydroxide ( $16.0 \mathrm{mg}, 280 \mu \mathrm{mol}, 0.01$ eq.) according to general procedure A. The crude product was further purified by column chromatography using petroleum ether/ethyl acetat 5:1 as the eluent to give a colorless solid $(2.08 \mathrm{~g}, 31 \%) .-{ }^{1} \mathrm{H}$ $\operatorname{NMR}\left(300 \mathrm{MHz}, \mathrm{CDCl}_{3}\right): \delta=8.07\left(\mathrm{~s}, 1 \mathrm{H}, \mathrm{C}_{\mathrm{ar}} \mathrm{H}\right), 7.37\left(\mathrm{~s}, 1 \mathrm{H}, \mathrm{C}_{\mathrm{ar}} H\right), 7.04\left(\mathrm{~s}, 1 \mathrm{H}, \mathrm{C}_{\mathrm{ar}} H\right.$ ), 2.23-2.34 $\left(\mathrm{m}, 2 \mathrm{H}, \mathrm{CH}_{2}\right), 2.04-2.10\left(\mathrm{~m}, 2 \mathrm{H}, \mathrm{CH}_{2}\right), 1.66-1.84\left(\mathrm{~m}, 6 \mathrm{H}, 3 \times \mathrm{CH}_{2}\right), 1.27-1.37(\mathrm{~m}, 4 \mathrm{H}, 2 \times$ $\left.\mathrm{CH}_{2}\right), 0.89\left(\mathrm{t},{ }^{3} \mathrm{~J}=7.1 \mathrm{~Hz}, 3 \mathrm{H}, \mathrm{CH}_{3}\right) .-{ }^{13} \mathrm{C}-\mathrm{NMR}\left(75 \mathrm{MHz}, \mathrm{CDCl}_{3}\right): \delta=145.4(\mathrm{C}=\mathrm{O}), 137.2\left(\mathrm{C}_{\mathrm{ar}} \mathrm{H}\right)$, $130.5\left(\mathrm{C}_{\mathrm{ar}} \mathrm{H}\right), 117.2\left(\mathrm{C}_{\mathrm{ar}} \mathrm{H}\right), 98.8\left(\mathrm{O}-\mathrm{C}_{\mathrm{q}}\right), 37.6\left(2 \times \mathrm{CH}_{2}\right), 36.8\left(\mathrm{CH}_{2}\right), 26.8\left(\mathrm{CH}_{2}\right), 24.0\left(2 \times \mathrm{CH}_{2}\right)$, $23.0\left(\mathrm{CH}_{2}\right), 14.1\left(\mathrm{CH}_{3}\right) .-$ FTIR: $\tilde{v}=2959,2872,1752,1469,1382,1286,1239,1171,999,772$ 
$\mathrm{cm}^{-1} .-\mathrm{MS}(\mathrm{ESI}), \mathrm{m} / \mathrm{z}(\%): 275\left[(\mathrm{M}+\mathrm{K})^{+}\right], 259\left[(\mathrm{M}+\mathrm{Na})^{+}\right], 236\left[\mathrm{M}^{+}\right] .-\mathrm{HRMS}\left(\mathrm{C}_{13} \mathrm{H}_{20} \mathrm{~N}_{2} \mathrm{O}_{2} \mathrm{Na}\right)$ : ber. 259.1422, gef. 259.1419. - HRMS $\left(\mathrm{C}_{13} \mathrm{H}_{20} \mathrm{~N}_{2} \mathrm{O}_{2} \mathrm{~K}\right)$ : ber. 275.1162, gef. 275.1159.

1-Pentylcyclopentyl $\mathbf{1 H}$-imidazole-1-carboxylate (7d): The reaction was carried out with 1,1carbonyldiimidazole (5) (1.96 g, $11.0 \mathrm{mmol}, 1.10$ eq.), 1-pentylcyclopentanol (6d) (1.56 g, $10.0 \mathrm{mmol}, 1.00$ eq.) and potassium hydroxide $(6.00 \mathrm{mg}, 100 \mu \mathrm{mol}, 0.01 \mathrm{eq}$.) according to general procedure $\mathbf{A}$. The crude product was further purified by column chromatography using petroleum ether/ethyl acetat 5:1 as the eluent to give a colorless solid (1.16 g, 46\%). ${ }^{1} \mathrm{H}-\mathrm{NMR}\left(300 \mathrm{MHz}, \mathrm{CDCl}_{3}\right): \delta=8.05\left(\mathrm{~s}, 1 \mathrm{H}, \mathrm{C}_{\mathrm{ar}} \mathrm{H}\right), 7.36\left(\mathrm{~s}, 1 \mathrm{H}, \mathrm{C}_{\mathrm{ar}} H\right), 7.03\left(\mathrm{~s}, 1 \mathrm{H}, \mathrm{C}_{\mathrm{ar}} H\right), 2.20-$ $2.33\left(\mathrm{~m}, 2 \mathrm{H}, \mathrm{CH}_{2}\right), 2.02-2.08\left(\mathrm{~m}, 2 \mathrm{H}, \mathrm{CH}_{2}\right), 1.65-1.82\left(\mathrm{~m}, 6 \mathrm{H}, 3 \times \mathrm{CH}_{2}\right), 1.22-1.38(\mathrm{~m}, 6 \mathrm{H}, 3$ $\left.\times \mathrm{CH}_{2}\right), 0.85\left(\mathrm{t},{ }^{3} \mathrm{~J}=7.0 \mathrm{~Hz}, 3 \mathrm{H}, \mathrm{CH}_{3}\right) \cdot-{ }^{13} \mathrm{C}-\mathrm{NMR}\left(75 \mathrm{MHz}, \mathrm{CDCl}_{3}\right): \delta=147.5(\mathrm{C}=\mathrm{O}), 137.2$ $\left(C_{\mathrm{ar}} \mathrm{H}\right), 130.5\left(\mathrm{C}_{\mathrm{ar}} \mathrm{H}\right), 117.3\left(\mathrm{C}_{\mathrm{ar}} \mathrm{H}\right), 98.9\left(\mathrm{O}-\mathrm{C}_{\mathrm{q}}\right), 37.5\left(2 \times \mathrm{CH}_{2}\right), 37.0\left(\mathrm{CH}_{2}\right), 32.1\left(\mathrm{CH}_{2}\right), 24.3\left(\mathrm{CH}_{2}\right)$, $24.0\left(2 \times \mathrm{CH}_{2}\right), 22.6\left(\mathrm{CH}_{2}\right), 14.6\left(\mathrm{CH}_{3}\right),-$ FTIR: $\tilde{v}=2957,2865,1749,1467,1378,1282,1236$, 1165, 1093, 1000, 771, $651 \mathrm{~cm}^{-1}$. - MS (ESI), m/z (\%): 523 (73) [(2M+Na) $\left.)^{+}\right] .-$HRMS $\left(\mathrm{C}_{28} \mathrm{H}_{44} \mathrm{~N}_{4} \mathrm{NaO}_{4}\right)$ : ber. 523.3260 , gef. 523.3267.

2-Methyloct-3-yn-2-yl $\mathbf{1 H}$-imidazole-1-carboxylate (7e): The reaction was carried out with 1,1-carbonyldiimidazole (5) (1.41 g, $7.92 \mathrm{mmol}, 1.10$ eq.), 2-methyloct-3-yn-2-ol (6e) (1.01 g, $7.20 \mathrm{mmol}, 1.00$ eq.) and potassium hydroxide $(4.00 \mathrm{mg}, 72.0 \mu \mathrm{mol}, 0.01 \mathrm{eq}$.) according to general procedure $\mathbf{A}$. The crude product was further purified by column chromatography using petroleum ether/ethyl acetat $10: 1$ as the eluent to give a colorless solid $(1.25 \mathrm{~g}, 74 \%)$. $-{ }^{1} \mathrm{H}-\mathrm{NMR}\left(300 \mathrm{MHz}, \mathrm{CDCl}_{3}\right): \delta=8.08\left(\mathrm{~s}, 1 \mathrm{H}, H_{\mathrm{ar}}\right), 7.38\left(\mathrm{~s}, 1 \mathrm{H}, H_{\mathrm{ar}}\right), 7.03\left(\mathrm{~s}, 1 \mathrm{H}, H_{\mathrm{ar}}\right), 2.21\left(\mathrm{t},{ }^{3} \mathrm{~J}\right.$ $\left.=7.0 \mathrm{~Hz}, 2 \mathrm{H}, \mathrm{CH}_{2}\right), 1.79\left(\mathrm{~s}, 6 \mathrm{H}, 2 \times \mathrm{CH}_{3}\right), 1.32-1.53\left(\mathrm{~m}, 4 \mathrm{H}, 2 \times \mathrm{CH}_{2}\right), 0.89\left(\mathrm{t},{ }^{3} \mathrm{~J}=7.2 \mathrm{~Hz}, 3 \mathrm{H}\right.$, $\left.\mathrm{CH}_{3}\right) .-{ }^{13} \mathrm{C}-\mathrm{NMR}\left(75 \mathrm{MHz}, \mathrm{CDCl}_{3}\right): \delta=146.7(C=\mathrm{O}), 137.3\left(C_{\mathrm{ar}} \mathrm{H}\right), 130.5\left(C_{\mathrm{ar}} \mathrm{H}\right), 117.3\left(C_{\mathrm{ar}} \mathrm{H}\right)$, $87.3\left(\mathrm{C}_{\mathrm{q}}-\mathrm{C}\right), 79.8\left(\mathrm{C}-\mathrm{CH}_{2}\right), 77.7\left(\mathrm{O}-\mathrm{C}_{\mathrm{q}}\right), 30.6\left(\mathrm{CH}_{2}\right), 29.5\left(2 \times \mathrm{CH}_{3}\right), 22.0\left(\mathrm{CH}_{2}\right), 18.5\left(\mathrm{CH}_{2}\right), 13.7$ $\left(\mathrm{CH}_{3}\right) .-$ FTIR: $\tilde{v}=2989,2933,2689,2247,1763,1468,1379,1291,1241,1125,1091,998$, 839, 769, $649 \mathrm{~cm}^{-1}$. - MS (EI), m/z (\%): $234(4)\left[\mathrm{M}^{+}\right], 123(100)\left[\left(\mathrm{C}_{9} \mathrm{H}_{15}\right)^{+}\right], 81(71)\left[\left(\mathrm{C}_{6} \mathrm{H}_{9}\right)^{+}\right] .-$ HRMS $\left(\mathrm{C}_{13} \mathrm{H}_{18} \mathrm{~N}_{2} \mathrm{O}_{2}\right)$ : ber. 234.1368 , gef. 234.1366.

1-(Hex-1-yn-1-yl)cyclohexyl $\mathbf{1 H}$-imidazole-1-carboxylate (7f): The reaction was carried out with 1,1-carbonyldiimidazole (5) (4.41 g, $24.8 \mathrm{mmol}, 1.10$ eq.), 1-(hex-1-yn-1-yl)cyclohexanol (6f) (4.06 g, $22.5 \mathrm{mmol}, 1.00$ eq.) and potassium hydroxide (13.0 mg, $225 \mu \mathrm{mol}, 0.01$ eq.) according to general procedure $\mathbf{A}$. The crude product was further purified by column chromatography using petroleum ether/ethyl acetat 5:1 as the eluent to give a colorless 
solid (5.24 g, 85\%). - ${ }^{1} \mathrm{H}-\mathrm{NMR}\left(300 \mathrm{MHz}, \mathrm{CDCl}_{3}\right): \delta=8.10\left(\mathrm{~s}, 1 \mathrm{H}, H_{\mathrm{ar}}\right), 7.40\left(\mathrm{~s}, 1 \mathrm{H}, H_{\mathrm{ar}}\right.$ ), 7.04 $\left(\mathrm{s}, 1 \mathrm{H}, H_{\mathrm{ar}}\right), 2.17-2.28\left(\mathrm{~m}, 4 \mathrm{H}, 2 \times \mathrm{CH}_{2}\right), 1.94-2.04\left(\mathrm{~m}, 2 \mathrm{H}, \mathrm{CH}_{2}\right), 1.30-1.71(\mathrm{~m}, 10 \mathrm{H}, 5 \times$ $\left.\mathrm{CH}_{2}\right), 0.90\left(\mathrm{t},{ }^{3} \mathrm{~J}=7.2 \mathrm{~Hz}, 3 \mathrm{H}, \mathrm{CH}_{3}\right) .-{ }^{13} \mathrm{C}-\mathrm{NMR}\left(75 \mathrm{MHz}, \mathrm{CDCl}_{3}\right): \delta=146.3(\mathrm{C}=\mathrm{O}), 137.2\left(\mathrm{C}_{\mathrm{ar}} \mathrm{H}\right)$, $130.4\left(\mathrm{C}_{\mathrm{ar}} \mathrm{H}\right), 117.2\left(\mathrm{C}_{\mathrm{ar}} \mathrm{H}\right), 89.0\left(\mathrm{C}_{\mathrm{q}}-\mathrm{C}\right), 81.2(\mathrm{C}-\mathrm{C}), 78.5\left(\mathrm{C}_{\mathrm{q}}\right), 37.5\left(2 \times \mathrm{CH}_{2}\right), 30.6\left(\mathrm{CH}_{2}\right), 25.0$ $\left(\mathrm{CH}_{2}\right), 22.9\left(2 \times \mathrm{CH}_{2}\right), 22.0\left(\mathrm{CH}_{2}\right), 18.5\left(\mathrm{CH}_{2}\right), 13.6\left(\mathrm{CH}_{3}\right) .-\mathrm{FTIR}: \tilde{\mathrm{v}}=2934,2860,2240,1763$, $1467,1378,1283,1234,1167,1092,996,893,830,765,742,649 \mathrm{~cm}^{-1}$. - MS (ESI), $\mathrm{m} / z$ (\%): $313\left[(\mathrm{M}+\mathrm{K})^{+}\right], 297\left[(\mathrm{M}+\mathrm{Na})^{+}\right]$. - HRMS $\left(\mathrm{C}_{16} \mathrm{H}_{22} \mathrm{~N}_{2} \mathrm{O}_{2} \mathrm{Na}\right)$ : ber. 297.1579, gef. 297.1574.

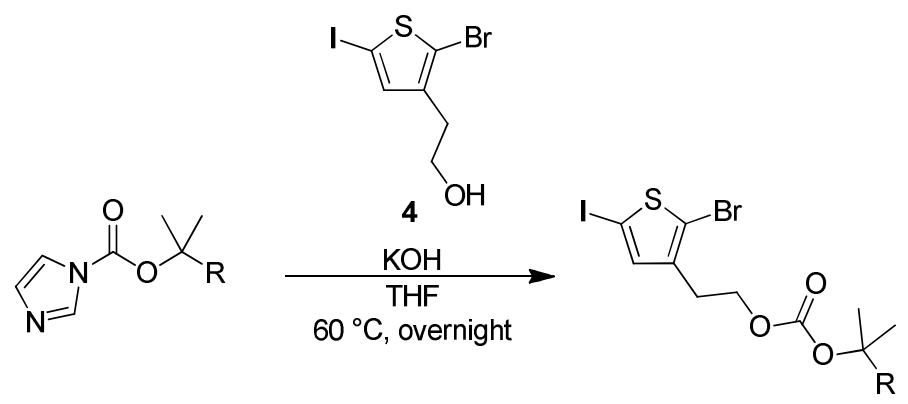

$7 a-j$

9a-f

Scheme S3: Synthesis of carbonates 9a-g.

Table S3: Thiophene monomers 9a-g prepared in this study.

\begin{tabular}{|c|c|c|c|}
\hline Entry & & Product & Yield [\%] \\
\hline 1 & $9 a$ & & 86 \\
\hline 2 & $9 b$ & & 84 \\
\hline 3 & $9 c$ & 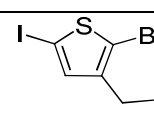 & 91 \\
\hline
\end{tabular}

ACS Paragon Plus Environment 


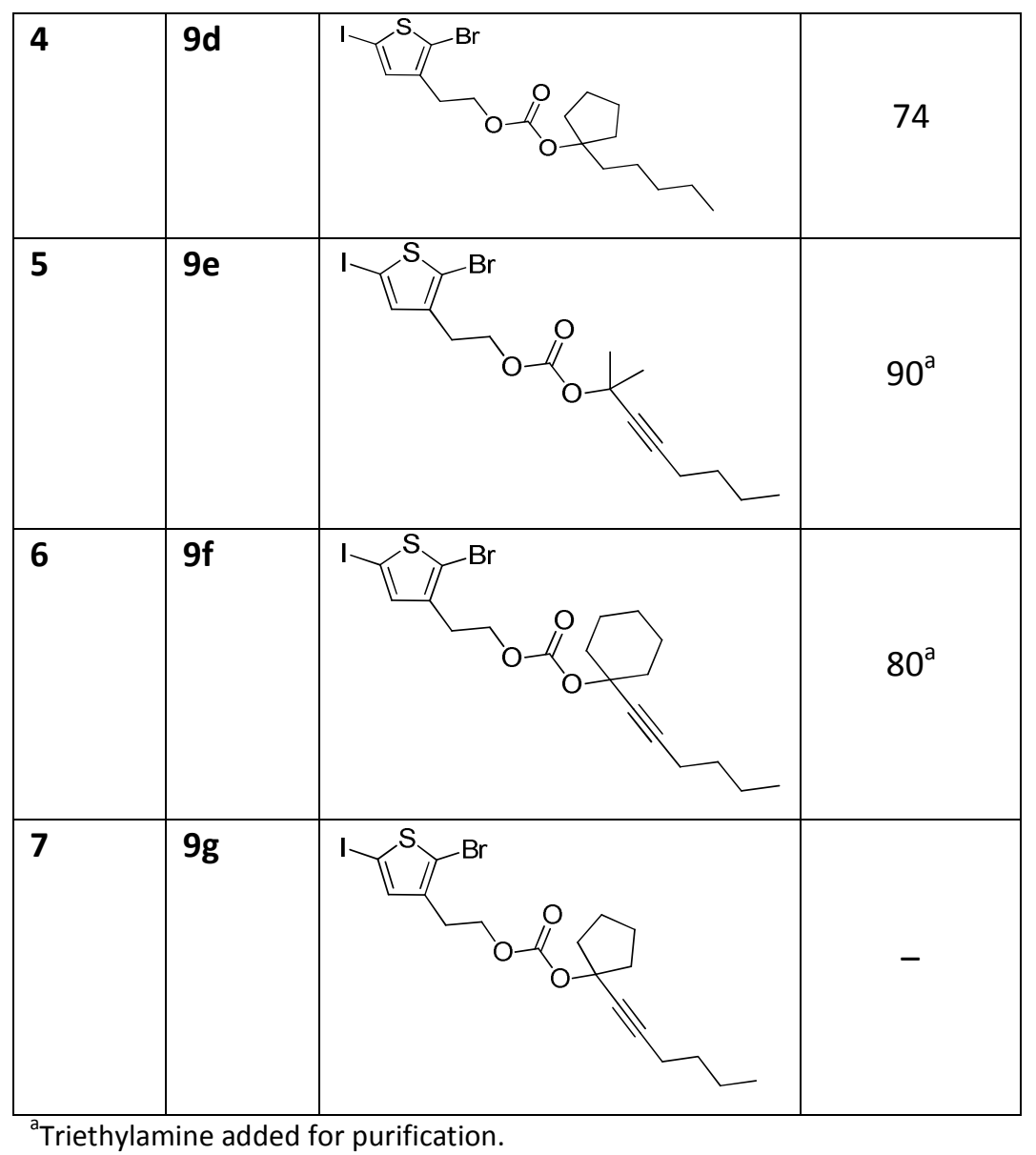

General procedure B for synthesis of thiophene monomers 9: To a solution of imidazole- $N$ carboxylic esters (7a-f) (1.10 eq.) and potassium hydroxide (0.01 eq.) in tetrahydrofuran (4.0 $\mathrm{mL} / \mathrm{mmol}$ ), 2-(2-bromo-5-iodothiophen-3-yl)ethanol (4) (1.00 eq.) in tetrahydrofuran (10 mL) was added dropwise. The reaction mixture was stirred at $60{ }^{\circ} \mathrm{C}$ overnight. The solution was left to cool and concentrated in vacuo. The residue was dissolved in dichloromethane and washed three times with water. The organic layer was collected and dried over anhydrous $\mathrm{MgSO}_{4}$. After filtration, the organic solvent was removed by evaporation under reduced pressure. The crude product was further purified by column chromatography using mixtures of petroleum ether/ethyl acetat as the eluent to give the thiophene monomers $\mathbf{9 a}-\mathbf{g}$.

2-(2-Bromo-5-iodothiophen-3-yl)ethyl (2-methylhexan-2-yl) carbonate (9a): The reaction was carried out with 2-methylhexan-2-yl $1 \mathrm{H}$-imidazole-1-carboxylate (7a) (694 mg, 3.30 mmol, 1.10 eq.), 2-(2-bromo-5-iodothiophen-3-yl)ethanol (4) (1.00 g, 3.00 mmol, 1.00 eq.) and potassium hydroxide $(2.00 \mathrm{mg}, 30.0 \mu \mathrm{mol}, 0.01$ eq.) according to general procedure $\mathbf{B}$. 
The crude product was further purified by column chromatography using petroleum ether/ethyl acetat 10:1 as the eluent to give a colorless oil $(1.23 \mathrm{~g}, 86 \%) .-{ }^{1} \mathrm{H}-\mathrm{NMR}$ (300 $\left.\mathrm{MHz}, \mathrm{CDCl}_{3}\right): \delta=7.02\left(\mathrm{~s}, 1 \mathrm{H}, \mathrm{H}_{\mathrm{ar}}\right), 4.20\left(\mathrm{t},{ }^{3} \mathrm{~J}=6.9 \mathrm{~Hz}, 2 \mathrm{H}, \mathrm{CH}_{2}-\mathrm{O}\right), 2.91\left(\mathrm{t},{ }^{3} \mathrm{~J}=6.9 \mathrm{~Hz}, 2 \mathrm{H}, \mathrm{C}_{\mathrm{ar}^{-}}\right.$ $\left.\mathrm{CH}_{2}\right), 1.73-1.78\left(\mathrm{~m}, 2 \mathrm{H}, \mathrm{C}_{\mathrm{q}}-\mathrm{CH}_{2}\right), 1.45\left(\mathrm{~s}, 6 \mathrm{H}, 2 \times \mathrm{CH}_{3}\right), 1.26-1.35\left(\mathrm{~m}, 4 \mathrm{H}, 2 \times \mathrm{CH}_{2}\right), 0.91\left(\mathrm{t},{ }^{3} \mathrm{~J}\right.$ $\left.=6.7 \mathrm{~Hz}, 3 \mathrm{H}, \mathrm{CH}_{3}\right) .-{ }^{13} \mathrm{C}-\mathrm{NMR}\left(75 \mathrm{MHz}, \mathrm{CDCl}_{3}\right): \delta=153.4(\mathrm{C}=0), 139.3\left(\mathrm{Car}_{\mathrm{ar}}-\mathrm{CH}_{2}\right), 138.2\left(\mathrm{Car}_{\mathrm{ar}}\right)$, $113.7\left(\mathrm{Car}_{\mathrm{ar}} \mathrm{Br}\right), 84.7\left(\mathrm{O}-\mathrm{C}_{\mathrm{q}}\right), 71.7\left(\mathrm{C}_{\mathrm{ar}}-\mathrm{I}\right), 65.3\left(\mathrm{CH}_{2}-\mathrm{O}\right), 40.4\left(\mathrm{C}_{\mathrm{q}}-\mathrm{CH}_{2}\right), 28.9\left(\mathrm{C}_{\mathrm{ar}}-\mathrm{CH}_{2}\right), 26.2\left(\mathrm{CH}_{2}\right)$, $25.8\left(2 \times \mathrm{CH}_{3}\right), 23.1\left(\mathrm{CH}_{2}\right), 14.2\left(\mathrm{CH}_{3}\right) .-$ FTIR: $\tilde{v}=2955,2930,2865,1736,1456,1385,1369$, 1271, 1249, 1213, 1154, 1092, 1074, 984, 957, 869, 826, 791, $472 \mathrm{~cm}^{-1}$. - MS (EI), m/z (\%): 476/474 (9/9) $\left[\mathrm{M}^{+}\right], 316 / 314(100 / 94)\left[\left(\mathrm{C}_{6} \mathrm{H}_{4} \mathrm{BrIS}\right)^{+}\right]$. - HRMS $\left(\mathrm{C}_{14} \mathrm{H}_{20} \mathrm{BrIO}_{3} \mathrm{~S}\right)$ : ber. 473.9361, gef. 473.9370 .

2-(2-Bromo-5-iodothiophen-3-yl)ethyl (1-cyclohexyl) carbonate (9b): The reaction was carried out with 1-methylcyclohexyl $1 \mathrm{H}$-imidazole-1-carboxylate (7b) $(687 \mathrm{mg}, 3.30 \mathrm{mmol}$, 1.10 eq.), 2-(2-bromo-5-iodothiophen-3-yl)ethanol (4) (1.00 g, $3.00 \mathrm{mmol}, 1.00$ eq.) and potassium hydroxide $(2.00 \mathrm{mg}, 30.0 \mu \mathrm{mol}, 0.01 \mathrm{eq}$.) according to general procedure $\mathbf{B}$. The crude product was further purified by column chromatography using petroleum ether/ethyl acetat 5:1 as the eluent to give a yellow oil $(1.19 \mathrm{~g}, 84 \%) .-{ }^{1} \mathrm{H}-\mathrm{NMR}\left(300 \mathrm{MHz}, \mathrm{CDCl}_{3}\right): \delta=$ $7.03\left(\mathrm{~s}, 1 \mathrm{H}, \mathrm{H}_{\mathrm{ar}}\right), 4.21\left(\mathrm{t},{ }^{3} \mathrm{~J}=7.0 \mathrm{~Hz}, 2 \mathrm{H}, \mathrm{CH}_{2}-\mathrm{O}\right), 2.92\left(\mathrm{t},{ }^{3} \mathrm{~J}=7.0 \mathrm{~Hz}, 2 \mathrm{H}, \mathrm{C}_{\mathrm{ar}}-\mathrm{CH}_{2}\right), 2.08-2.15$ (m, $\left.2 \mathrm{H}, \mathrm{C}_{\mathrm{q}}-\mathrm{CH}_{2}\right), 1.20-1.61\left(\mathrm{~m}, 8 \mathrm{H}, 4 \times \mathrm{CH}_{2}\right), 1.48\left(\mathrm{~s}, 3 \mathrm{H}, \mathrm{CH}_{3}\right) .-{ }^{13} \mathrm{C}-\mathrm{NMR}\left(75 \mathrm{MHz}, \mathrm{CDCl}_{3}\right): \delta$ $=153.3(C=0), 139.4\left(C_{a r}-C_{2}\right), 138.3\left(C_{a r}\right), 113.7\left(C_{a r}-B r\right), 84.0\left(0-C_{q}\right), 71.7\left(C_{a r}-1\right), 65.3\left(C_{2^{-}}\right.$ O), $36.6\left(2 \times \mathrm{CH}_{2}\right), 27.1\left(\mathrm{CH}_{2}\right), 25.5\left(\mathrm{C}_{\mathrm{ar}}-\mathrm{CH}_{2}\right), 25.2\left(\mathrm{CH}_{3}\right), 22.3\left(2 \times \mathrm{CH}_{2}\right) .-$ FTIR: $\tilde{\mathrm{v}}=2931,2859$, 1734, 1445, $1228 \mathrm{~cm}^{-1}$. - MS (EI), m/z (\%): 474/472 (6/5) [M $], 316 / 314$ (100/94) $\left[\left(\mathrm{C}_{6} \mathrm{H}_{4} \mathrm{BrIS}\right)^{+}\right]$. - HRMS $\left(\mathrm{C}_{14} \mathrm{H}_{18} \mathrm{BrIO}_{3} \mathrm{~S}\right)$ : ber. 471.9205, gef. 471.9199.

2-(2-Bromo-5-iodothiophen-3-yl)ethyl (1-butylcyclopentyl) carbonate (9c): The reaction was carried out with 1-butylcyclopentyl $1 \mathrm{H}$-imidazole-1-carboxylate (7c) $(1.01 \mathrm{~g}, 4.30 \mathrm{mmol}$, 1.10 eq.), 2-(2-bromo-5-iodothiophen-3-yl)ethanol (4) (1.30 g, $3.90 \mathrm{mmol}, 1.00$ eq.) and potassium hydroxide $(2.00 \mathrm{mg}, 39.0 \mu \mathrm{mol}, 0.01 \mathrm{eq}$.) according to general procedure $\mathbf{B}$. The crude product was further purified by column chromatography using petroleum ether/ethyl acetat 10:1 as the eluent to give a colorless oil $(1.77 \mathrm{~g}, 91 \%) .-{ }^{1} \mathrm{H}-\mathrm{NMR}\left(300 \mathrm{MHz}, \mathrm{CDCl}_{3}\right): \delta=$ $7.02\left(\mathrm{~s}, 1 \mathrm{H}, \mathrm{H}_{\mathrm{ar}}\right), 4.21\left(\mathrm{t},{ }^{3} \mathrm{~J}=6.7 \mathrm{~Hz}, 2 \mathrm{H}, \mathrm{CH}_{2}-\mathrm{O}\right), 2.91\left(\mathrm{t},{ }^{3} \mathrm{~J}=6.7 \mathrm{~Hz}, 2 \mathrm{H}, \mathrm{C}_{\mathrm{ar}}-\mathrm{CH}_{2}\right), 2.07-2.18$ $\left(\mathrm{m}, 2 \mathrm{H}, \mathrm{C}_{\mathrm{q}}-\mathrm{CH}_{2}\right), 1.89-1.97\left(\mathrm{~m}, 2 \mathrm{H}, \mathrm{CH}_{2}\right), 1.57-1.79\left(\mathrm{~m}, 6 \mathrm{H}, 3 \times \mathrm{CH}_{2}\right), 1.25-1.35(\mathrm{~m}, 4 \mathrm{H}, 2 \times$ $\left.\mathrm{CH}_{2}\right), 0.90\left(\mathrm{t},{ }^{3} \mathrm{~J}=6.9 \mathrm{~Hz}, 3 \mathrm{H}, \mathrm{CH}_{3}\right) .{ }^{13} \mathrm{C}-\mathrm{NMR}\left(75 \mathrm{MHz}, \mathrm{CDCl}_{3}\right): \delta=153.5(\mathrm{C}=0), 139.3\left(\mathrm{Car}^{-}\right.$ 
$\left.\mathrm{CH}_{2}\right), 138.2\left(\mathrm{Car}_{\mathrm{ar}} \mathrm{H}\right), 113.7\left(\mathrm{Car}_{\mathrm{ar}} \mathrm{Br}\right), 95.5\left(\mathrm{O}-\mathrm{C}_{\mathrm{q}}\right), 71.8\left(\mathrm{Car}_{\mathrm{r}} \mathrm{-}\right), 65.4\left(\mathrm{CH}_{2}-\mathrm{O}\right), 37.5\left(2 \times \mathrm{CH}_{2}\right), 36.7$ $\left(\mathrm{CH}_{2}\right), 29.0\left(\mathrm{CH}_{2}\right), 27.1\left(\mathrm{CH}_{2}\right), 24.1\left(2 \times \mathrm{CH}_{2}\right), 23.1\left(\mathrm{CH}_{2}\right), 14.2\left(\mathrm{CH}_{3}\right) .-\mathrm{FTIR}: \tilde{v}=2959,2870$, 1735, 1453, 1388, 1251, 1172, 1102, 965, $792 \mathrm{~cm}^{-1}$. - MS (Fab), m/z (\%): 502/500 [M+]. HRMS $\left(\mathrm{C}_{16} \mathrm{H}_{22} \mathrm{BrIO}_{3} \mathrm{~S}\right)$ : ber. 499.9518 , gef. 499.9489 .

2-(2-Bromo-5-iodothiophen-3-yl)ethyl (1-pentylcyclopentyl) carbonate (9d): The reaction was carried out with 1-butylcyclopentyl $1 \mathrm{H}$-imidazole-1-carboxylate (7d) $(1.01 \mathrm{~g}, 4.30 \mathrm{mmol}$, 1.10 eq.), 2-(2-bromo-5-iodothiophen-3-yl)ethanol (4) (1.30 g, $3.90 \mathrm{mmol}, 1.00$ eq.) and potassium hydroxide $(2.00 \mathrm{mg}, 39.0 \mu \mathrm{mol}, 0.01 \mathrm{eq}$.) according to general procedure $\mathbf{B}$. The crude product was further purified by column chromatography using petroleum ether/ethyl acetat $10: 1$ as the eluent to give a colorless oil $(1.77 \mathrm{~g}, 91 \%) .-{ }^{1} \mathrm{H}-\mathrm{NMR}\left(300 \mathrm{MHz}, \mathrm{CDCl}_{3}\right): \delta=$ $7.02\left(\mathrm{~s}, 1 \mathrm{H}, \mathrm{H}_{\mathrm{ar}}\right), 4.20\left(\mathrm{t},{ }^{3} \mathrm{~J}=7.0 \mathrm{~Hz}, 2 \mathrm{H}, \mathrm{CH}_{2}-\mathrm{O}\right), 2.90\left(\mathrm{t},{ }^{3} \mathrm{~J}=7.0 \mathrm{~Hz}, 2 \mathrm{H}, \mathrm{C}_{\mathrm{ar}}-\mathrm{CH}_{2}\right), 2.06-2.17$ (m, $\left.2 \mathrm{H}, \mathrm{C}_{\mathrm{q}}-\mathrm{CH}_{2}\right), 1.89-1.95\left(\mathrm{~m}, 2 \mathrm{H}, \mathrm{CH}_{2}\right), 1.57-1.77\left(\mathrm{~m}, 6 \mathrm{H}, 3 \times \mathrm{CH}_{2}\right), 1.23-1.36(\mathrm{~m}, 6 \mathrm{H}, 3 \times$ $\left.\mathrm{CH}_{2}\right), 0.87\left(\mathrm{t},{ }^{3} \mathrm{~J}=6.6 \mathrm{~Hz}, 3 \mathrm{H}, \mathrm{CH}_{3}\right) .-{ }^{13} \mathrm{C}-\mathrm{NMR}\left(75 \mathrm{MHz}, \mathrm{CDCl}_{3}\right): \delta=153.5(\mathrm{C}=0), 139.3\left(\mathrm{Car}^{-}\right.$ $\left.\mathrm{CH}_{2}\right), 138.2\left(\mathrm{Car}_{\mathrm{ar}} \mathrm{H}\right), 113.6\left(\mathrm{Car}_{\mathrm{ar}} \mathrm{Br}\right), 95.5\left(\mathrm{O}-\mathrm{C}_{\mathrm{q}}\right), 71.7\left(\mathrm{Car}_{\mathrm{ar}} \mathrm{-}\right), 65.4\left(\mathrm{CH}_{2}-\mathrm{O}\right), 37.5\left(\mathrm{CH}_{2}\right), 36.9(2 \times$ $\left.\mathrm{CH}_{2}\right), 32.2\left(\mathrm{CH}_{2}\right), 28.9\left(\mathrm{CH}_{2}\right), 24.2\left(\mathrm{CH}_{2}\right), 24.1\left(2 \times \mathrm{CH}_{2}\right), 22.7\left(\mathrm{CH}_{2}\right), 14.2\left(\mathrm{CH}_{3}\right) .-\mathrm{FTIR}: \tilde{v}=$ 2954, 2865, 1735, 1454, 1259, 1201, 983, $792 \mathrm{~cm}^{-1}$. - MS (ESI), $m / z(\%): 554 / 552$ [(M+K) $\left.{ }^{+}\right]$. HRMS ( $\left.\mathrm{C}_{17} \mathrm{H}_{24} \mathrm{BrIO}_{3} \mathrm{SK}\right)$ : ber. 552.9311, gef. 552.9312 .

2-(2-Bromo-5-iodothiophen-3-yl)ethyl (2-methyloct-3-yn-2-yl) carbonate (9e): The reaction was carried out with 2-methyloct-3-yn-2-yl $1 H$-imidazole-1-carboxylate (7e) $(1.29 \mathrm{~g}, 5.50$ mmol, 1.10 eq.), 2-(2-bromo-5-iodothiophen-3-yl)ethanol (4) (1.67 g, 5.00 mmol, 1.00 eq.) and potassium hydroxide ( $3.00 \mathrm{mg}, 50.0 \mu \mathrm{mol}, 0.01 \mathrm{eq}$.) according to general procedure $\mathbf{B}$. The crude product was further purified by column chromatography using petroleum ether/ethyl acetat 10:1 and triethylamine (2 vol.-\%) as the eluent to give a yellow oil (2.25 g, 90\%). $-{ }^{1} \mathrm{H}-\mathrm{NMR}\left(300 \mathrm{MHz}, \mathrm{CDCl}_{3}\right): \delta=7.03\left(\mathrm{~s}, 1 \mathrm{H}, \mathrm{H}_{\mathrm{ar}}\right), 4.23\left(\mathrm{t},{ }^{3} \mathrm{~J}=6.9 \mathrm{~Hz}, 2 \mathrm{H}, \mathrm{CH}_{2}-\mathrm{O}\right), 2.92$ $\left(\mathrm{t},{ }^{3} \mathrm{~J}=6.9 \mathrm{~Hz}, 2 \mathrm{H}, \mathrm{C}_{\mathrm{ar}}-\mathrm{CH}_{2}\right), 2.21\left(\mathrm{t},{ }^{3} \mathrm{~J}=6.9 \mathrm{~Hz}, 2 \mathrm{H}, \mathrm{C}-\mathrm{CH}_{2}\right), 1.67\left(\mathrm{~s}, 6 \mathrm{H}, 2 \times \mathrm{CH}_{3}\right), 1.33-1.53$ $\left(\mathrm{m}, 4 \mathrm{H}, 2 \times \mathrm{CH}_{2}\right), 0.90\left(\mathrm{t},{ }^{3} \mathrm{~J}=7.1 \mathrm{~Hz}, 3 \mathrm{H}, \mathrm{CH}_{3}\right) .-{ }^{13} \mathrm{C}-\mathrm{NMR}\left(75 \mathrm{MHz}, \mathrm{CDCl}_{3}\right): \delta=152.9(\mathrm{C}=\mathrm{O})$, $139.3\left(C_{\mathrm{ar}}-\mathrm{CH}_{2}\right), 138.2\left(\mathrm{C}_{\mathrm{ar}} \mathrm{H}\right), 113.7\left(\mathrm{C}_{\mathrm{ar}}-\mathrm{Br}\right), 85.6\left(C-\mathrm{CH}_{2}\right), 80.7\left(C-\mathrm{C}_{\mathrm{q}}\right), 75.3\left(\mathrm{O}-\mathrm{C}_{\mathrm{q}}\right), 71.7\left(C_{\mathrm{ar}}-\mathrm{I}\right)$, $65.7\left(\mathrm{CH}_{2}-\mathrm{O}\right), 30.7\left(\mathrm{CH}_{2}\right), 29.3\left(2 \times \mathrm{CH}_{3}\right), 28.9\left(\mathrm{CH}_{2}\right), 22.0\left(\mathrm{CH}_{2}\right), 18.5\left(\mathrm{CH}_{2}\right), 13.7\left(\mathrm{CH}_{3}\right)$. - FTIR: $\tilde{v}=2958,2930,2867,2245,1748,1463,1384,1250,1194,1132,1100,790 \mathrm{~cm}^{-1} .-M S(E I)$, $m / z(\%): 500 / 498(12 / 12)\left[\mathrm{M}^{+}\right], 316 / 314(100 / 95)\left[\left(\mathrm{C}_{6} \mathrm{H}_{4} \mathrm{BrIS}\right)^{+}\right], 236(25)\left[\left(\mathrm{C}_{6} \mathrm{H}_{5} \mathrm{IS}\right)^{+}\right], 123(61)$ $\left[\left(\mathrm{C}_{9} \mathrm{H}_{15}\right)^{+}\right]$. - HRMS $\left(\mathrm{C}_{16} \mathrm{H}_{20} \mathrm{BrIO}_{3} \mathrm{~S}\right)$ : ber. 497.9361, gef. 497.9385. 
2-(2-Bromo-5-iodothiophen-3-yl)ethyl (1-(hex-1-yn-1-yl)cyclohexyl) carbonate (9f): The reaction was carried out with 1-(hex-1-yn-1-yl)cyclohexyl $1 \mathrm{H}$-imidazole-1-carboxylate (7f) (1.51 g, $5.50 \mathrm{mmol}, 1.10$ eq.), 2-(2-bromo-5-iodothiophen-3-yl)ethanol (4) (1.67 g, 5.00 mmol, 1.00 eq.) and potassium hydroxide ( $3.00 \mathrm{mg}, 50.0 \mu \mathrm{mol}, 0.01$ eq.) according to general procedure B. The crude product was further purified by column chromatography using petroleum ether/ethyl acetat 20:1 and triethylamine ( 2 vol.-\%) as the eluent to give a yellow oil (2.17 g, 80\%). - ${ }^{1} \mathrm{H}-\mathrm{NMR}\left(300 \mathrm{MHz}^{\mathrm{CDCl}} \mathrm{CDC}_{3}\right): \delta=7.03\left(\mathrm{~s}, 1 \mathrm{H}, \mathrm{Har}_{\mathrm{ar}}\right), 4.24\left(\mathrm{t},{ }^{3} \mathrm{~J}=7.2 \mathrm{~Hz}\right.$, $\left.2 \mathrm{H}, \mathrm{CH}_{2}-\mathrm{O}\right), 2.93\left(\mathrm{t},{ }^{3} \mathrm{~J}=7.2 \mathrm{~Hz}, 2 \mathrm{H}, \mathrm{C}_{\mathrm{ar}}-\mathrm{CH}_{2}\right), 2.25\left(\mathrm{t},{ }^{3} \mathrm{~J}=7.2 \mathrm{~Hz}, 2 \mathrm{H}, \mathrm{C}-\mathrm{CH}_{2}\right), 2.09-2.17(\mathrm{~m}, 2$ $\left.\mathrm{H}, \mathrm{CH}_{2}\right), 1.77-1.86\left(\mathrm{~m}, 2 \mathrm{H}, \mathrm{CH}_{2}\right), 1.60-1.68\left(\mathrm{~m}, 4 \mathrm{H}, 2 \times \mathrm{CH}_{2}\right), 1.39-1.45\left(\mathrm{~m}, 6 \mathrm{H}, 3 \times \mathrm{CH}_{2}\right)$, $0.91\left(\mathrm{t},{ }^{3} \mathrm{~J}=7.2 \mathrm{~Hz}, 3 \mathrm{H}, \mathrm{CH}_{3}\right) .-{ }^{13} \mathrm{C}-\mathrm{NMR}\left(75 \mathrm{MHz}, \mathrm{CDCl}_{3}\right): \delta=152.8(\mathrm{C}=\mathrm{O}), 139.3\left(\mathrm{C}_{\mathrm{ar}}-\mathrm{CH}_{2}\right)$, $138.2\left(C_{a r} H\right), 113.7\left(C_{a r}-\mathrm{Br}\right), 87.9\left(C-C_{2}\right), 79.5\left(C-C_{q}\right), 79.0\left(O-C_{q}\right), 71.9\left(C_{a r}-1\right), 65.7\left(C_{2}-O\right)$, $37.5\left(2 \times \mathrm{CH}_{2}\right), 30.9\left(\mathrm{CH}_{2}\right), 27.1\left(\mathrm{CH}_{2}\right), 25.3\left(2 \times \mathrm{CH}_{3}\right), 23.1\left(\mathrm{CH}_{2}\right), 22.1\left(\mathrm{CH}_{2}\right), 18.7\left(\mathrm{CH}_{2}\right), 13.8$ $\left(\mathrm{CH}_{3}\right) .-$ FTIR: $\tilde{v}=2930,2857,2240,1745,1447,1267,1231,1182,1125,1014,917,782 \mathrm{~cm}^{-1}$. - MS (FAB), m/z (\%): 541/539 (67/100) $\left[(\mathrm{M}+\mathrm{H})^{+}\right], \quad 540 / 538 \quad(50 / 47) \quad\left[\mathrm{M}^{+}\right] . \quad$ - HRMS $\left(\mathrm{C}_{19} \mathrm{H}_{24} \mathrm{BrlO}_{3} \mathrm{~S}\right)$ : ber. 537.9674, gef. 537.9725.

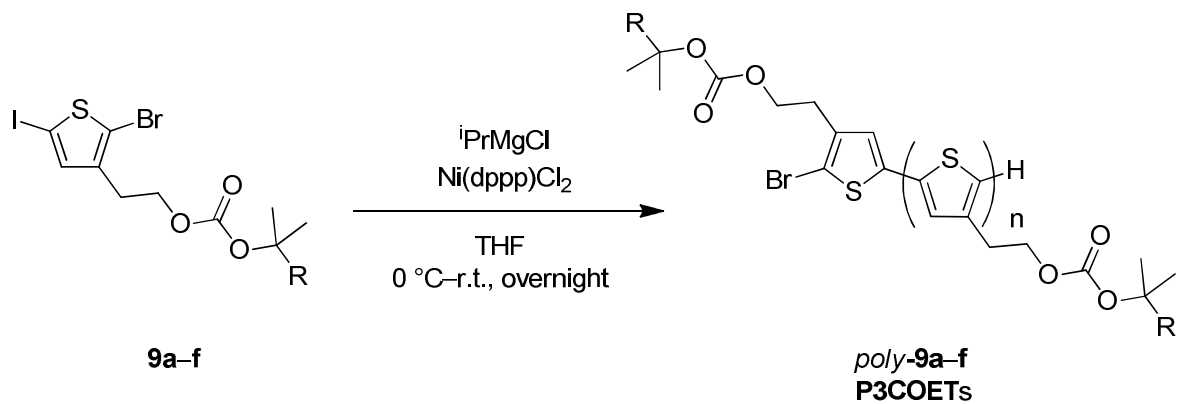

Scheme S4: KCT Polymerization of carbonates 9a-f.

General procedure $\mathbf{C}$ for synthesis of P3COETs poly-9: A solution of thiophene monomers (9a-f) $\left(1.00\right.$ eq.) in tetrahydrofuran $(5.0 \mathrm{~mL} / \mathrm{mmol})$ was stirred at $0{ }^{\circ} \mathrm{C}$. To the mixture was added a $2.0 \mathrm{M}$ isopropylmagnesium chloride solution in diethyl ether (1.00 eq.) and the mixture was stirred at $0{ }^{\circ} \mathrm{C}$ for $1 \mathrm{~h}$. Then a suspension of 1,3-bis(diphenylphosphino)propane nickel(II) chloride (0.005 eq.) in tetrahydrofuran $(5.0 \mathrm{~mL})$ was added to the mixture at $0{ }^{\circ} \mathrm{C}$, and then the mixture was stirred at room temperature. After the reaction mixture had been 
stirred for $24 \mathrm{~h}, 5 \mathrm{M}$ hydrochloric acid was added and the mixture was extracted with chloroform. The organic layer was washed with water, dried over anhydrous $\mathrm{MgSO}_{4}$, and concentrated under reduced pressure. The product was redissolved in chloroform and was poured in methanol. The insoluble material was purified by Soxhlet extraction (methanol, acetone, chloroform) to give the polythiophenes poly-9a-f.

Poly(2-methylhexan-2-yl 2-(thiophen-3-yl)ethyl carbonate) (poly-9a): The reaction was carried out with 2-(2-bromo-5-iodothiophen-3-yl)ethyl (2-methylhexan-2-yl) carbonate (9a) (4.66 g, $9.80 \mathrm{mmol}, 1.00$ eq.), $2.0 \mathrm{M}$ isopropylmagnesium chloride solution (4.9 mL, $1.01 \mathrm{~g}$, $9.80 \mathrm{mmol}, 1.00$ eq.) and 1,3-bis(diphenylphosphino)propane nickel(II) chloride $(27.0 \mathrm{mg}$, $49.0 \mu \mathrm{mol}, 0.005$ eq.) according to general procedure $\mathbf{C}$. The crude product was further purified by Soxhlet extraction to give a red solid (acetone: $1.02 \mathrm{~g}, 39 \%$; chloroform: $382 \mathrm{mg}$, 15\%). $-{ }^{1} \mathrm{H}-\mathrm{NMR}\left(300 \mathrm{MHz}, \mathrm{CDCl}_{3}\right): \delta=7.10\left(\mathrm{~s}, 1 \mathrm{H}, \mathrm{H}_{\mathrm{ar}}\right), 4.36\left(\mathrm{~m}, 2 \mathrm{H}, \mathrm{CH}_{2}-\mathrm{O}\right), 3.18(\mathrm{~m}, 2 \mathrm{H}$, $\left.\mathrm{C}_{\mathrm{ar}}-\mathrm{CH}_{2}\right), 1.73-1.81\left(\mathrm{~m}, 2 \mathrm{H}, \mathrm{C}_{\mathrm{q}}-\mathrm{CH}_{2}\right), 1.46\left(\mathrm{~s}, 6 \mathrm{H}, 2 \times \mathrm{CH}_{3}\right), 1.26-1.35\left(\mathrm{~m}, 4 \mathrm{H}, 2 \times \mathrm{CH}_{2}\right), 0.85-$ $0.92\left(\mathrm{~m}, 3 \mathrm{H}, \mathrm{CH}_{3}\right)$. - SEC (PSS-standard): acetone: $\mathrm{M}_{\mathrm{n}}=15.3 \mathrm{~kg} \mathrm{~mol}^{-1}, \mathrm{M}_{\mathrm{w}}=24.6 \mathrm{~kg} \mathrm{~mol}^{-1}, \mathrm{PDI}$ $=1.61$; Chloroform: $\mathrm{M}_{\mathrm{n}}=41.0 \mathrm{~kg} \mathrm{~mol}^{-1}, \mathrm{M}_{\mathrm{w}}=45.6 \mathrm{~kg} \mathrm{~mol}^{-1}, \mathrm{PDI}=1.11 .-\mathrm{FTIR}: \tilde{v}=2955$, 2932, 2865, 1733, 1456, 1386, 1368, 1269, 1246, 1212, 1153, 1073, 938, 862, 831, $790 \mathrm{~cm}^{-1}$. - TGA/DSC (10 K/min, $5 \%$ weight loss): $192^{\circ} \mathrm{C}$. - UV-Vis (chloroform): absorption: solution = $437 \mathrm{~nm}$, film $=475 \mathrm{~nm}$; emission: solution $=563 \mathrm{~nm}$, film $=628 \mathrm{~nm} .-\mathrm{CV}$ (as film against $\mathrm{Fc} / \mathrm{Fc}^{+}$in acetonitrile): $\mathrm{E}^{\mathrm{ox}}=0.518 \mathrm{~V}$.

Poly(1-methylcyclohexyl 2-(thiophen-3-yl)ethyl carbonate) (poly-9b): The reaction was carried out with 2-(2-bromo-5-iodothiophen-3-yl)ethyl (1-methylcyclohexyl) carbonate (9b) (1.11 g, $2.35 \mathrm{mmol}, 1.00$ eq.), $2.0 \mathrm{M}$ isopropylmagnesium chloride solution (1.1 mL, $242 \mathrm{mg}$, $2.35 \mathrm{mmol}, 1.00$ eq.) and 1,3-bis(diphenylphosphino)propane nickel(II) chloride $(6.00 \mathrm{mg}$, $12.0 \mu \mathrm{mol}, 0.005$ eq.) according to general procedure $\mathbf{C}$. The crude product was further purified by Soxhlet extraction to give a red solid (chloroform: $165 \mathrm{mg}, 26 \%$ ). $-{ }^{1} \mathrm{H}-\mathrm{NMR}$ (300 $\left.\mathrm{MHz}, \mathrm{CDCl}_{3}\right): \delta=7.11\left(\mathrm{~s}, 1 \mathrm{H}, \mathrm{H}_{\mathrm{ar}}\right), 4.30-4.40\left(\mathrm{~m}, 2 \mathrm{H}, \mathrm{CH}_{2}-\mathrm{O}\right), 3.12-3.21\left(\mathrm{~m}, 2 \mathrm{H}, \mathrm{C}_{\mathrm{ar}}-\mathrm{CH}_{2}\right)$, 2.08-2.17 (m, $\left.2 \mathrm{H}, \mathrm{C}_{\mathrm{q}}-\mathrm{CH}_{2}\right), 1.41-1.59\left(\mathrm{~m}, 11 \mathrm{H}, 4 \times \mathrm{CH}_{2}+\mathrm{CH}_{3}\right)$. - SEC (PSS-standard): acetone: $\mathrm{M}_{\mathrm{n}}=5.51 \mathrm{~kg} \mathrm{~mol}^{-1}, \mathrm{M}_{\mathrm{w}}=7.28 \mathrm{~kg} \mathrm{~mol}^{-1}, \mathrm{PDI}=1.32 ;$ Chloroform: $\mathrm{M}_{\mathrm{n}}=18.4 \mathrm{~kg} \mathrm{~mol}^{-1}$, $\mathrm{M}_{\mathrm{w}}=22.9 \mathrm{~kg} \mathrm{~mol}^{-1}, \mathrm{PDI}=1.25 .-\mathrm{FTIR}: \tilde{\mathrm{v}}=2930,2859,1732,1444,1372,1294,1263,1228$, 1150, 1088, 1040, 957, 870, $793 \mathrm{~cm}^{-1}$. - TGA/DSC (10 K/min, 5\% weight loss): $194{ }^{\circ} \mathrm{C} .-\mathrm{UV}$ Vis (chloroform): absorption: solution $=436 \mathrm{~nm}$; emission: solution $=562 \mathrm{~nm}$. 
Poly(1-butylcyclopentyl 2-(thiophen-3-yl)ethyl carbonate) (poly-9c): The reaction was carried out with 2-(2-bromo-5-iodothiophen-3-yl)ethyl (1-butylcyclopentyl) carbonate (9c) (1.55 g, $3.10 \mathrm{mmol}, 1.00$ eq.), $2.0 \mathrm{M}$ isopropylmagnesium chloride solution (1.6 mL, $319 \mathrm{mg}$, $3.10 \mathrm{mmol}, 1.00$ eq.) and 1,3-bis(diphenylphosphino)propane nickel(II) chloride (8.00 mg, $16.0 \mu \mathrm{mol}, 0.005$ eq.) according to general procedure $\mathbf{C}$. The crude product was further purified by Soxhlet extraction to give a red solid (chloroform: $85.0 \mathrm{mg}, 5 \%$ ). - SEC (PSSstandard): chloroform: $M_{n}=22.2 \mathrm{~kg} \mathrm{~mol}^{-1}, \mathrm{M}_{\mathrm{w}}=27.5 \mathrm{~kg} \mathrm{~mol}^{-1}, \mathrm{PDI}=1.24 .-\mathrm{FTIR}: \tilde{v}=2954$, 2866, 134, 1452, 1251, $960 \mathrm{~cm}^{-1}$. - TGA/DSC (10 K/min, 5\% weight loss): $140{ }^{\circ} \mathrm{C}$ - - UV-Vis (chloroform): absorption: solution $=430 \mathrm{~nm}$; emission: solution $=562 \mathrm{~nm}$.

Poly(1-pentylcyclopentyl 2-(thiophen-3-yl)ethyl carbonate) (poly-9d): The reaction was carried out with 2-(2-bromo-5-iodothiophen-3-yl)ethyl (1-pentylcyclopentyl) carbonate (9d) (2.72 g, $5.30 \mathrm{mmol}, 1.00$ eq.), $2.0 \mathrm{M}$ isopropylmagnesium chloride solution $(2.7 \mathrm{~mL}, 545 \mathrm{mg}$, $5.30 \mathrm{mmol}, 1.00$ eq.) and 1,3-bis(diphenylphosphino)propane nickel(II) chloride (14.0 mg, $27.0 \mu \mathrm{mol}, 0.005$ eq.) according to general procedure C. The crude product was further purified by Soxhlet extraction to give a red solid (acetone: $30.0 \mathrm{mg}, 3 \%$ ). - SEC (PSSstandard): acetone: $M_{n}=4.33 \mathrm{~kg} \mathrm{~mol}^{-1}, \mathrm{M}_{\mathrm{w}}=4.83 \mathrm{~kg} \mathrm{~mol}^{-1}, \mathrm{PDI}=1.12 .-\mathrm{FTIR}: \tilde{\mathrm{v}}=2955$, 2926, 2856, 1737, 1456, 1257, 1009, $791 \mathrm{~cm}^{-1}$. - TGA/DSC (10 K/min, 5\% weight loss): $168^{\circ} \mathrm{C}$. - UV-Vis (chloroform): absorption: solution $=429 \mathrm{~nm}$; emission: solution $=562 \mathrm{~nm}$.

Poly(2-methyloct-3-yn-2-yl 2-(thiophen-3-yl)ethyl carbonate) (poly-9e): The reaction was carried out with 2-(2-bromo-5-iodothiophen-3-yl)ethyl (2-methyloct-3-yn-2-yl) carbonate (9e) $(2.50 \mathrm{~g}, 5.00 \mathrm{mmol}, 1.00$ eq.), $2.0 \mathrm{M}$ isopropylmagnesium chloride solution $(2.5 \mathrm{~mL}, 514$ $\mathrm{mg}, 5.00 \mathrm{mmol}, 1.00$ eq.) and 1,3-bis(diphenylphosphino)propane nickel(II) chloride (14.0 $\mathrm{mg}, 25.0 \mu \mathrm{mol}, 0.005$ eq.) according to general procedure $\mathbf{C}$. The crude product was further purified by Soxhlet extraction to give a red solid (chloroform: $290 \mathrm{mg}, 20 \%$ ). - SEC (PSSstandard): acetone: $M_{n}=8.23 \mathrm{~kg} \mathrm{~mol}^{-1}, \mathrm{M}_{\mathrm{w}}=10.9 \mathrm{~kg} \mathrm{~mol}^{-1}, \mathrm{PDI}=1.32 .-\mathrm{FTIR}: \tilde{v}=2959$, $2867,1745,1461,1383,1250,1129,1096,783 \mathrm{~cm}^{-1}$. - TGA/DSC (10 K/min, 5\% weight loss): $174{ }^{\circ} \mathrm{C}$. UV-Vis (chloroform): absorption: solution $=431 \mathrm{~nm}$, film $=474 \mathrm{~nm}$; emission: solution $=561 \mathrm{~nm}$, film $=609 \mathrm{~nm}$.

Poly(1-(hex-1-yn-1-yl)cyclohexyl 2-(thiophen-3-yl)ethyl carbonate) (poly-9f): The reaction was carried out with 2-(2-bromo-5-iodothiophen-3-yl)ethyl (1-(hex-1-yn-1-yl)cyclohexyl) carbonate (9f) (1.89 g, $3.50 \mathrm{mmol}, 1.00$ eq.), $2.0 \mathrm{M}$ isopropylmagnesium chloride solution 
(1.8 mL, $360 \mathrm{mg}, 3.50 \mathrm{mmol}, 1.00$ eq.) and 1,3-bis(diphenylphosphino)propane nickel(II) chloride $(9.00 \mathrm{mg}, 18.0 \mu \mathrm{mol}, 0.005$ eq.) according to general procedure $\mathbf{C}$. The crude product was further purified by Soxhlet extraction to give a red solid (acetone: $273 \mathrm{mg}$, 23\%). - SEC (PSS-standard): acetone: $\mathrm{M}_{\mathrm{n}}=17.9 \mathrm{~kg} \mathrm{~mol}^{-1}, \mathrm{M}_{\mathrm{w}}=31.7 \mathrm{~kg} \mathrm{~mol}^{-1}, \mathrm{PDI}=1.77$. FTIR: $\tilde{v}=2929,2856,1744,1447,1264,127,1179,1009,894,790 \mathrm{~cm}^{-1} .-$ TGA/DSC (10 $\mathrm{K} / \mathrm{min}, 5 \%$ weight loss): $178{ }^{\circ} \mathrm{C}$. - UV-Vis (chloroform): absorption: solution = $428 \mathrm{~nm}$; emission: solution $=560 \mathrm{~nm}$.

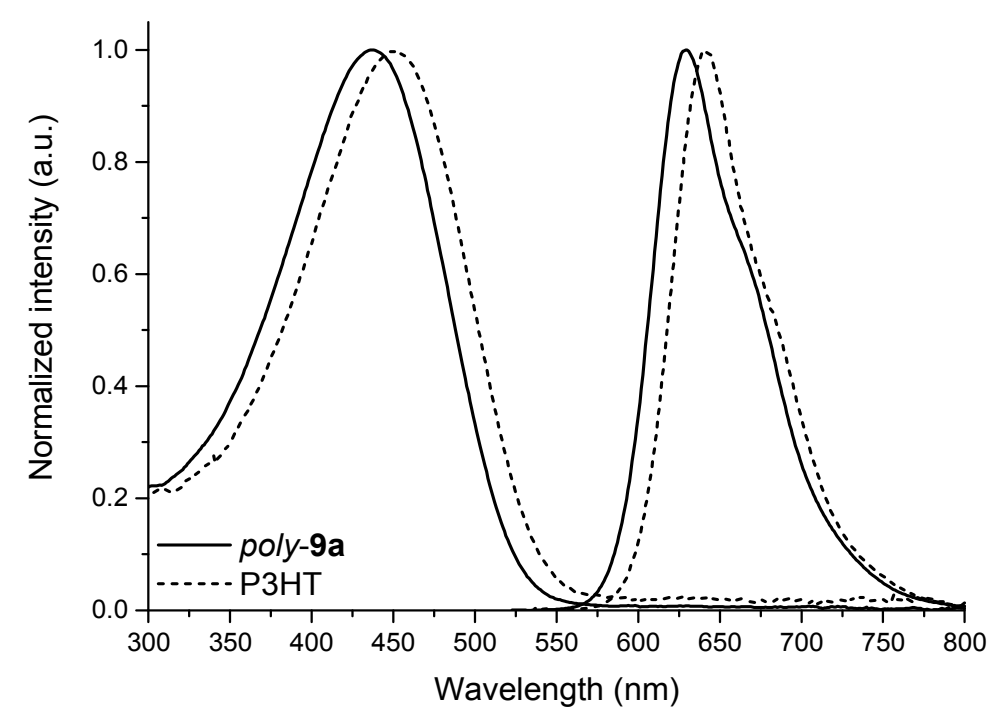

Figure S1: Normalized absorption and emission spectra of P3COETs poly-9a (solid) and P3HT (dashed).

\section{S2. Grazing Incidence Wide Angle X-ray Scattering (GIWAXS)}

GIWAXS measurements of poly-9a drop cast films were performed at the DELTA Synchrotron using beamline BL09 with a photon energy of $10 \mathrm{keV}\left(\lambda=1.2398 \AA^{-1}\right)$. The scattering intensity was detected on a 2-D image plate (MAR-345) with a pixel size of $150 \mu \mathrm{m}(2300 \times 2300$ pixels), and the detector was placed $345 \mathrm{~mm}$ from the sample center. Data analysis was performed using the Datasqueeze software. The beam size was $0.05 \mathrm{~mm} \times 0.5 \mathrm{~mm}$ and samples were irradiated just below the critical angle for total reflection with respect to the incoming X-ray beam $\left(\sim 0.18^{\circ}\right)$. 
GIWAXS experiments of the sample in OPV architecture and for poly-9a spin coated film were performed by means of a solid anode X-ray tube (Siemens Kristalloflex X-ray source, copper anode X-ray tube operated at $30 \mathrm{kV}$ and $20 \mathrm{~mA}$ ). Osmic confocal MaxFlux optics, Xray beam with pinhole collimation and a MAR345 image plate detector. The samples were prepared as thin film with the same procedure as it was used in OPVs fabrication with one change as a substrate the silicon/silicon dioxide was used.
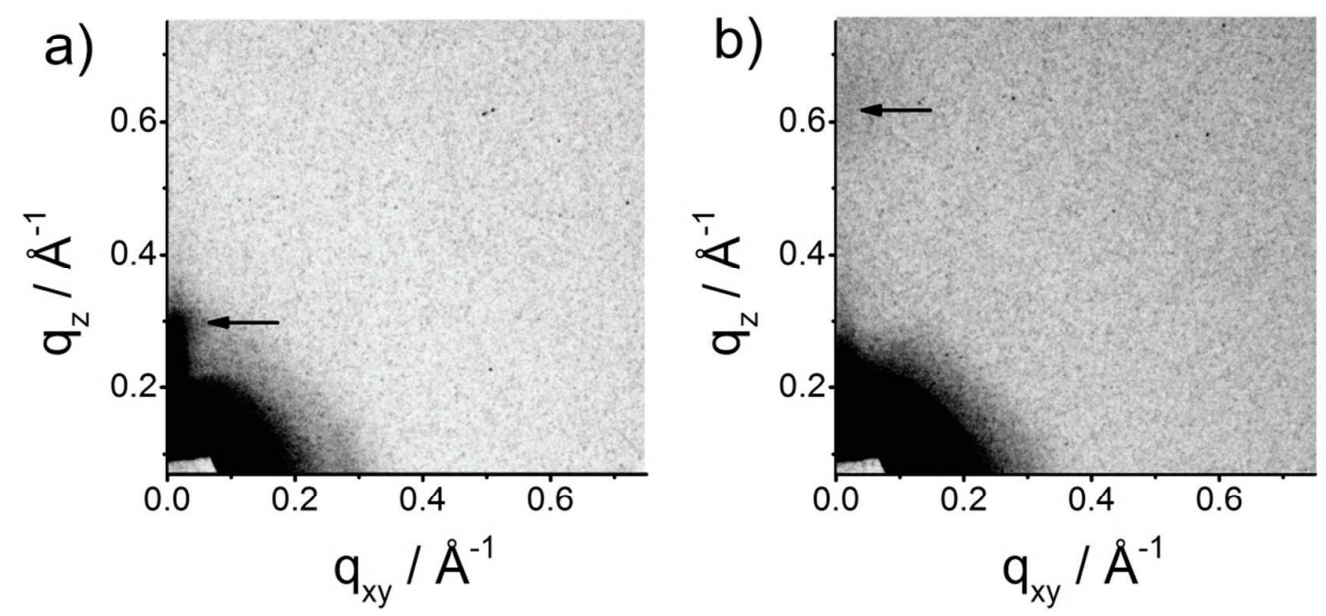

Figure S2. GIWAXS patterns of thin films of spin coated P3COET poly-9a after annealing (a) at $100^{\circ} \mathrm{C}$ and (b) after annealing at $150^{\circ} \mathrm{C}(72 \mathrm{~h})$. Meridional reflection related to the interlayer structure is indicated by black arrows in the GIWAXS patterns.

\section{S3. Field-Effect Transistors}

To find the relation between thermal cleavage and charge carrier mobility, poly-9a has been employed as an exemplary active material in transistors. The field-effect transistors (FET) were processed using bottom gate, bottom contact architecture with gold source and drain electrodes. The $300 \mathrm{~nm}$ thick $\mathrm{SiO}_{2}$ dielectric covering the highly doped $\mathrm{Si}$ acting as the gate electrode was functionalized with hexamethyldisilazane (HMDS) to minimize interfacial trapping sites. Poly-9a thin films were deposited by drop-casting $2 \mathrm{mg} / \mathrm{mL}$ chloroform solution on FET substrates in nitrogen atmosphere. The channel lengths and widths are 10 and $700 \mathrm{~mm}$, respectively. All the fabrication procedures and electrical measurements (using Keithley 4200 SCS) were performed in a glove box under nitrogen atmosphere.

In order to compare the charge carrier transport before and after thermal cleavage, FETs were measured after thermal annealing at two different temperatures: below $\left(100{ }^{\circ} \mathrm{C}\right)$, to ensure evaporation of residual solvent and order improvement by polymer reorganization, 
and at $200^{\circ} \mathrm{C}$, i.e., above the cleavage temperature $\left(192{ }^{\circ} \mathrm{C}\right)$. Transfer characteristics presented on Figure S3 do not show any significant difference in the charge carrier transport before and after thermal annealing at $200{ }^{\circ} \mathrm{C}$. The charge carrier mobility in both cases is at the same, relatively low level $\mu=10^{-5} \mathrm{~cm}^{2} / \mathrm{Vs}$. We assumed that this moderate charge carrier mobility likely originates from low molecular arrangement of the polymer backbones in the thin-films (amorphous structure). This in turn may result from relatively long alkyl chains (more than C6) which reduce charge transport in regioregular polythiophene derivatives [A. Babel, S.A. Jenekhe / Synthetic Metals 148 (2005) 169-173]. We conclude that thermal reduction of the substituent length in drop cast film does not improve the charge carrier mobility. The most likely reason for such behavior is the thickness of the semiconducting and consequently a less efficient thermo-cleavage process next to dielectric/semiconductor interface.
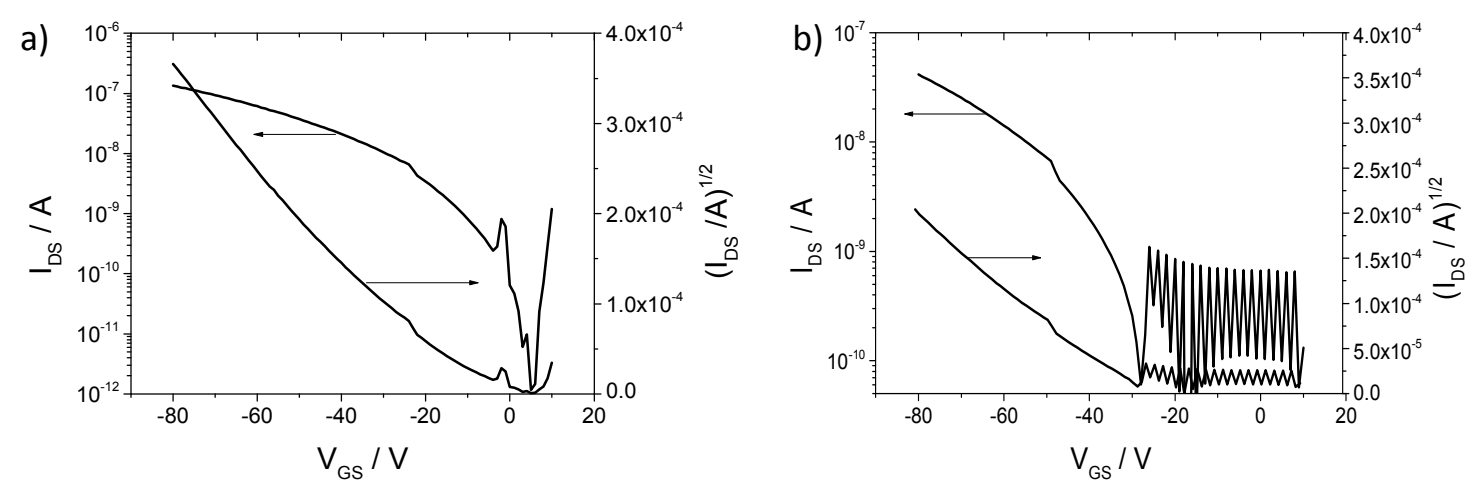

Figure S3. Transfer characteristic at $\mathrm{V}_{\mathrm{DS}}=-80 \mathrm{~V}$ for the poly-9a-based transistors obtained after thermal annealing (a) at $100{ }^{\circ} \mathrm{C}(12 \mathrm{~h})$ and (b) at $200{ }^{\circ} \mathrm{C}(1 \mathrm{~h})$.

\section{S4. Organic Solar Cell Fabrication and Characterization}

Solar cells were fabricated on indium tin oxide (ITO) coated glass (ShinAn SNP, $\mathrm{R}_{\text {sheet }} \approx 13 \Omega / \mathrm{sq}$ ). The ITO substrates were structured in hydrochloric acid and ultrasonically cleaned in acetone and isopropanol. To polarize the surface and to remove organic residues, the samples were exposed to an oxygen plasma (120 s). After cleaning, the substrates were transferred into a glove box and kept under dry nitrogen atmosphere $\left(<0.1 \mathrm{ppm} \mathrm{O}_{2}\right.$ and $\left.\mathrm{H}_{2} \mathrm{O}\right)$ throughout the entire fabrication process. Then, a $20 \mathrm{~nm}$ thick layer of low-conductive poly(3,4-ethylenedioxythiophene):polystyrenesulfonate (PEDOT:PSS, Heraeus Clevios VPAI 4083) was spin coated on top. To remove residual water from the PEDOT:PSS layer, the 
samples were stored on a hotplate at a temperature of $120^{\circ}{ }^{\wedge} \mathrm{C}$ for $15 \mathrm{~min}$. Subsequently, the active layer comprising a blend of poly-9a and PCBM (Solenne BV, $40 \mathrm{mg} / \mathrm{ml}, 1: 0.5$ - 1:1.25) was spin coated from dichlorobenzene. Then the samples were thermally annealed on a hotplate at $150^{\circ} \mathrm{C}$ and $200^{\circ} \mathrm{C}$ for 10 minutes, respectively. Finally, the $\mathrm{Ca} / \mathrm{Al}$ electrodes were evaporated $\left(1 \AA \mathrm{s}^{-1}\right.$ and $\left.3 \AA \mathrm{s}^{-1}\right)$ through a shadow mask under high vacuum $\left(3 \times 10^{-6} \mathrm{mbar}\right)$. The current density-voltage $(J-V)$ characteristics were measured with a source measurement unit (Keithley 238) under nitrogen atmosphere. A solar simulator (Oriel $300 \mathrm{~W}$ ) was used to simulate sunlight according to the ASTM G-173-03 AM1.5 standard. The solar simulator light intensity was monitored with a calibrated spectrometer in order to minimize the spectral mismatch within the relevant wavelength regime. 
TOC graphic

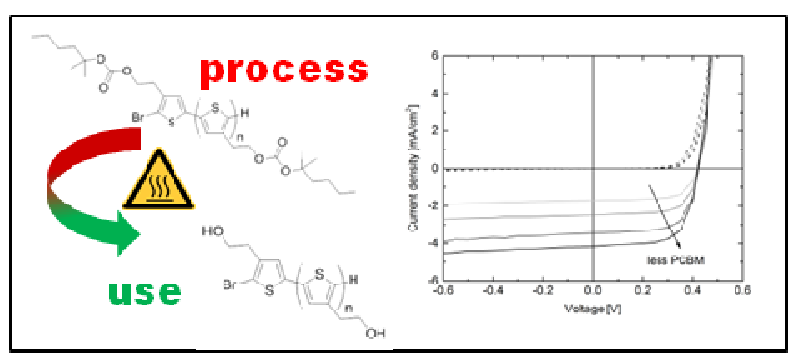

1

2

3

4

5

6

7

10

11

12

13

14

15

16

17

18

19

20

21

22

23

24

25

26

27

28

29

30

31

32

33

34

35

36

37

38

39

40

41

42

43

44

45

46

47

48

49

50

51

52

53

54

55

56

57

58

59

60 